\title{
A QUANTITATIVE STUDY OF TWO POPULATIONS OF THE MOTH PANAXIA DOMINULA (L.)
}

\author{
P. M. SHEPPARD
}

Genetics Laboratory, Department of Zoology, University of Oxford

\section{CONTENTS}

Received 3I.iii.5I

I Introduction.

2. A Description of a New Variety and Some New Observations on the Behaviour of the Moth. . . . 350

3. The Sheepstead Hurst Colony and Changes in the Cothill Colony 354

4. The Selective Value of the Medionigra Gene at Cothill . . 356

5. The Estimation of Daily and Seasonal Population Size . $\quad 362$

6. Discussion . . . . . . . . . . . 374

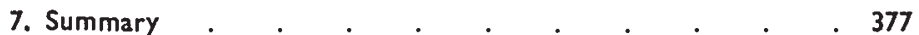

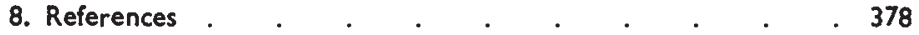

\section{INTRODUCTION}

BETWEEN I939 and I946 an intensive study of an isolated population of the moth Panaxia dominula (L.) was carried out by Fisher and Ford (1947) at Cothill. They were able to estimate the number of moths flying in the colony from day to day, as well as the total population size for the season. Moreover, because the seasonal population size was known, they were able to demonstrate that the observed fluctuations in the frequency of a gene, which showed no dominance, were too great to be ascribed to random sampling in the reproduction of the population, a process which is often referred to as "genetic drift." Wright (1948) has criticised their results on the grounds that no population size was calculated for I939 or I940. However, the population in $194^{\circ}$ would have to have been as small as the number of moths actually caught to invalidate their results. Even if collecting had been carried out on every day of the season, the population could not have been less than $45^{\circ}$ since the data for other years show that they never caught as much as a quarter of the population in the season.

In the winter of 1948 , when looking for larvæ of $P$. dominula in all the suitable areas in the vicinity of Cothill, to see if there were any populations which had been overlooked by entomologists, I found that there was a small colony still in existence in Tubney Wood, where the moth was supposed to be extinct (Kettlewell, 1942). I also found a large colony at Sheepstead Hurst, just over a mile down the stream which runs through Cothill. Because very much more information can be obtained by the comparison of the ecology of two or more populations, than by the intensive study of one, it was decided 
to investigate the new colony at Sheepstead Hurst as well as the original one at Cothill. It was impossible to study adequately all three breeding-communities at the same time.

The purpose of this paper is to give an account of the results obtained from the continued study of the colony of $P$. dominula at Cothill and a comparison of this population and the newly discovered one at Sheepstead Hurst.

\section{A DESCRIPTION OF A NEW VARIETY AND SOME NEW OBSERVATIONS ON THE BEHAVIOUR OF THE MOTH}

A detailed description of $P$. dominula and its habits has been given by Kettlewell (1942) and a comprehensive summary of his conclusions, with special reference to the situation at Cothill, may be obtained from the paper by Fisher and Ford (1947). However, since 1946 a new form of the moth has been discovered and more observations have been made on the habits of $P$. dominula. In 1948 a variety of the moth, which I shall call var. A for convenience, was discovered in copulation with a normal female at Cothill. It has the elongated black spot near the anal angle of the hind-wing split into two spots and the area covered by the white and yellow marks on the fore-wing slightly increased. A brood from this female of the new form was successfully raised. It produced seven normal males, eleven normal females and five males and seven females of var. A. No specimens of the new form were found in any other broods raised from normal wild females nor in any other stocks of $P$. dominula kept under similar conditions in the laboratory. The only pairing of the form var. A from which a brood was successfully raised in 1950, was produced by a female which mated with a normal male from another stock. Twenty-four moths emerged in July $195^{\circ}$ and all of them were normal. In the collections of the Hope Department of Entomology at Oxford there are five normal insects which were raised from a pairing of two moths, one of which was var. A. In the Tring collection there is an example of the new form from Winchester, where most of the moths are var. A, which had paired with a normal $P$. dominula from Cothill. There are a large number of offspring from this mating all of which are var. A. However, it is not known if all the progeny of this pairing or the one in the Hope Department are present. It seems certain that the new form is inherited, perhaps as a simple recessive, but it must be remembered that temperature has a considerable effect on the amount of black pigment deposited on the wings of $P$. dominula. It is possible therefore, that the expression of the inherited factors responsible may be modified by the environment. Breeding experiments are being continued to elucidate these points. It has been possible to record the percentage of var. $\mathrm{A}$ in the Cothill colony in 1948, 1949 and 1950, as well as the proportion in the Sheepstead Hurst population in 1949 and 1950. A few intermediate 
forms between var. A and typical $P$. dominula are found, therefore the arbitrary decision was made that if one of the spots on the two hind-wings was split the moth was recorded as var. A (table 9). The proportions of the new form in the two colonies are different, although whether the difference is purely genetic or both environmental and genetic, is not yet known. In the Cothill population some specimens of var. medionigra Cockayne, are also var. A.

It has been stated by Fisher and Ford (1947) that the moth usually emerges from the pupa in the morning and that many of the females pair at once. However, from observations at Cothill and Sheepstead Hurst as well as from breeding experiments in the laboratory, it appears that females do not start assembling males in large numbers before about 2.30 p.m. (G.M.T.) and that they may continue until dusk. It follows that the majority of them must mate in the afternoon as males are not attracted after copulation has taken place. In the laboratory even those females which have emerged some days previously, do not pair readily until the afternoon on the day on which they are put into a cage with males. Kettlewell (I942) believes that females do not fly until the day after copulation and that because they start laying eggs soon after pairing they must lay a considerable proportion of their eggs in the vicinity of the food plant on which they themselves had fed as larvæ. Seven females which had been found mating at Cothill were given a distinctive mark and released in the normal way (page 363 ). The position in which they came to rest was carefully noted and a thorough search of the area was made the next morning. No female was ever recaptured in this area, although twice a female was caught in a different place. The method of release might upset the normal behaviour of the insect, consequently, the same marking procedure was carried out at Sheepstead Hurst, without disturbing the moths. Six different females found in copulation were used and again none of them was discovered in the same place on the next day. Moreover, fifty females from wild larvæ, which paired on the same day that they emerged were kept in the laboratory in 1950. They were put in separate boxes, which were all about the same size, and shape, and maintained at a temperature of about $60^{\circ} \mathrm{F}$. The number of eggs laid each day was recorded together with the length of life of the insect. It was found that females seldom deposited many eggs until the day after copulation and that in the first twenty-four hours they only laid a small proportion of the total number of eggs. However, it must be remembered that the moths were in artificial conditions and that their expectation of life was far higher than in the field.

A summary of the results of this experiment is given in table $I$. A significant correlation with $\mathrm{P}<0.00 \mathrm{I}$, was found between the length of life of females and the total number of eggs deposited (table 2). Even if there are other factors effecting the death-rate in the wild there must still be a correlation between the length of life of a female 
and the number of eggs laid. Consequently, the death-rate of adults must be one of the factors, although probably a minor one, in controlling the change in population size from year to year. Among

TABLE I

\begin{tabular}{|c|c|c|c|}
\hline $\begin{array}{c}\text { Periods of 24 hours } \\
\text { after copulation }\end{array}$ & $\begin{array}{c}\text { Number of insects } \\
\text { alive }\end{array}$ & Eggs deposited & $\begin{array}{c}\text { Percentage of total number } \\
\text { of eggs deposited by } \\
\text { the population }\end{array}$ \\
\cline { 2 - 3 } 1 & 47 & 2,394 & $18 \cdot 2$ \\
2 & 46 & 1,812 & $13 \cdot 7$ \\
3 & 45 & 2,248 & $17 \cdot 1$ \\
4 & 44 & 1,707 & $13 \cdot 0$ \\
5 & 44 & 1,341 & $10 \cdot 2$ \\
6 & 44 & 883 & $6 \cdot 7$ \\
7 & 42 & 994 & $7 \cdot 5$ \\
8 & 42 & 618 & $4 \cdot 7$ \\
9 & 40 & 394 & $3 \cdot 0$ \\
10 & 34 & 348 & $2 \cdot 6$ \\
11 & 31 & 223 & $1 \cdot 7$ \\
12 & 25 & 118 & $0 \cdot 9$ \\
13 & 22 & 77 & $0 \cdot 6$ \\
14 & 12 & 15 & $0 \cdot 1$ \\
15 & 7 & 9 & $0 \cdot 1$ \\
16 & 1 & 0 & $0 \cdot 0$ \\
\hline & & 13,181 & $100 \cdot 1$ \\
\hline
\end{tabular}

TABLE 2

Total number of eggs deposited by individuals

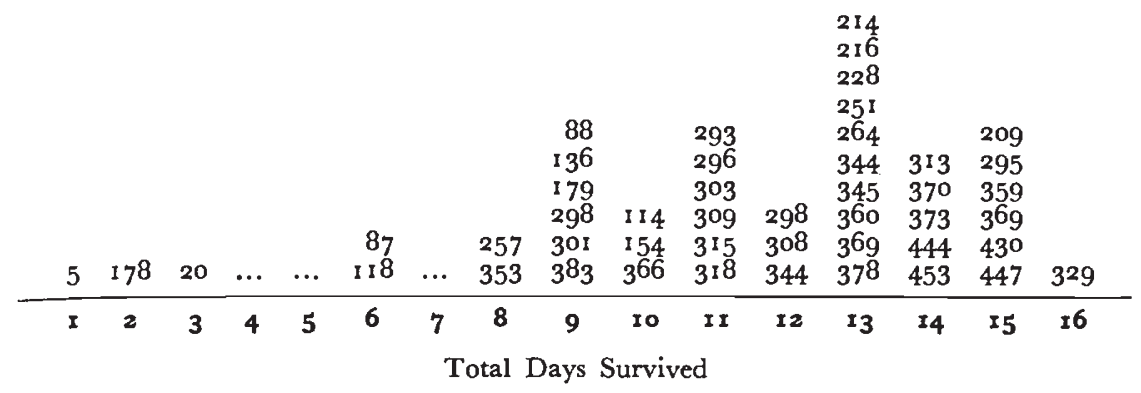

the moths investigated, there were three abnormal individuals two of which laid very few eggs in the first seven days and produced no fertile eggs. They both lived eighteen days which was longer than any of the others survived except one which deposited no eggs at all and lived twenty-nine days. The results from these three aberrant individuals supports the view that moths which cannot lay fertile eggs have a greater expectation of life than those which have mated successfully and that therefore their chance of a fertile mating at a later date is increased.

All the evidence suggests that the females do not lay a large pro- 
portion of their eggs in the vicinity of the plants on which they themselves fed as larvæ, but that the majority are deposited in other areas of the colony. During the breeding experiments it was discovered that the males very frequently pair several times (one moth paired ten times with different females) and that the females all deposit their normal number of fertile eggs. On the other hand, females were never observed to pair more than once, except very rarely at the end of their lives, when they had started to lay infertile eggs or when they had previously copulated unsuccessfully. The ability of the males, but not the females, to pair on a large number of occasions is of considerable importance in understanding the significance of changes in the sex-ratio during the season (page 372 ).

Fisher and Ford (1947) have suggested that the pattern on the fore-wings of $P$. dominula makes them rather inconspicuous, especially when they are resting on the flower heads of Hemp Agrimony, Eupatorium cannabinum L., and they point out that when the moths are touched they often display the scarlet hind-wings and produce two large drops of amber coloured fluid from the prothorax. However, they did not draw attention to the fact that when they are flying, with their characteristic undulating flight, the scarlet hind-wings produce a flashing effect which makes it very difficult to follow their line of flight. When they suddenly land there is a typical flash colouration effect. In fact this species does not only show cryptic colouration of the ruptive type and warning colouration when violently disturbed but also flash colouration. In this connection it is of interest that on several occasions dragon flies have been seen to catch the moths and then drop them almost immediately. The few times the moths could be discovered in the long grass where they had fallen, they were never found to be severely damaged.

Fisher and Ford (1 947) investigated the fluctuations in the frequency of a gene which shows no dominance and, except as a great rarity, is found only in the colony at Cothill. The heterozygotes are known as var. medionigra Cockayne and homozygotes as var. bimacula Cockayne. Kettlewell (1942) states that in the breeding cage preferential pairings take place between individuals carrying this gene. However, there is no evidence of this from the field, judged by the ratio of the three phenotypes, taking into account their relative selective advantages (page 359). In fact less var. bimacula have been found than would be expected if their selective disadvantage is as great as the square of the selective value of the heterozygote. However, this is not conclusive, since it might be greater than this value. Kettlewell's evidence is not based on any strict numerical data but only on observations in breeding cages containing a large number of individuals. In these cages any one pairing will alter the ratio of the genotypes which can pair in the future. It was therefore decided to make a number of similar cages and to put three moths in each, two being of one sex, and one of the other. If two of the moths are var. medionigra and the 
third typical dominula or two dominula and the other medionigra, four combinations can be obtained.

(a) One female dominula and one female medionigra with one male dominula.

(b) The same as (a) with a male medionigra substituted for the male dominula.

(c) A male dominula and a male medionigra with a female medionigra.

(d) The same as (c) with a female dominula substituted for the female medionigra.

Consequently, in each cage either the male or the female had a " choice" of mates. If there is no differential pairing there would be an even chance of either mating taking place first. The results of the first pairings are as follows :-

$\begin{array}{lccc} & \text { dominula } \times \text { dominula } & \text { dominula } \times \text { medionigra } & \text { medionigra } \times \text { medionigra } \\ (a) & \mathrm{I} & 2 & \ldots \\ (b) & \ldots & 3 & 1 \\ (c) & \ldots & 3 & 2 \\ (d) & 5 & 6 & \ldots\end{array}$

Different varieties pairing, 14 ; same varieties pairing 9.

No tendency for similar varieties to pair with one another has been demonstrated, but the experiment must be considerably enlarged before really useful results will be obtained. However, there should have been some indication of any tendency for preferential matings which was large enough to be detected, with any certainty, by casual observation. In fact the discrepancy from the expected one to one ratio is in the opposite direction, although there is no suggestion of it being significant $\mathrm{P}>0 \cdot 20$.

\section{THE SHEEPSTEAD HURST COLONY AND CHANGES IN THE COTHILL COLONY}

The population at Sheepstead Hurst, which was discovered in the winter of 1948 , occupies a damp wood just over a mile south of the village of Cothill and on the same tributary of the Ock which drains the Cothill marsh. Agricultural land borders the stream both north and south of the colony and also surrounds the wood. Consequently, the population is well isolated from both the Cothill and Tubney Wood habitats. The wood itself is growing in a peat marsh which resembles Cothill in many respects except that it is much damper and there is always a quantity of stagnant water surrounding the reeds (Phragmites communis Trin.) and tussocks of grass in the old peat workings. These pits form open spaces in the wood on its northern border and in these clearings Alder and Birch scrub is growing. $P$. dominula is most abundant in these open spaces and is only slightly less common in the thin belt of marshy grassland to the north and 
west of the high hedge surrounding the wood, as well as down the stream on its eastern border. In fact $P$. dominula is common in all areas except the densely wooded part at the southern end of the colony. Large quantities of Comfrey (Symphytum officinale L.) grow in the grassy areas surrounding the wood and on the banks of the stream but not in any quantity inside the wood or in the peat workings. On the other hand, the dense masses of $P$. communis

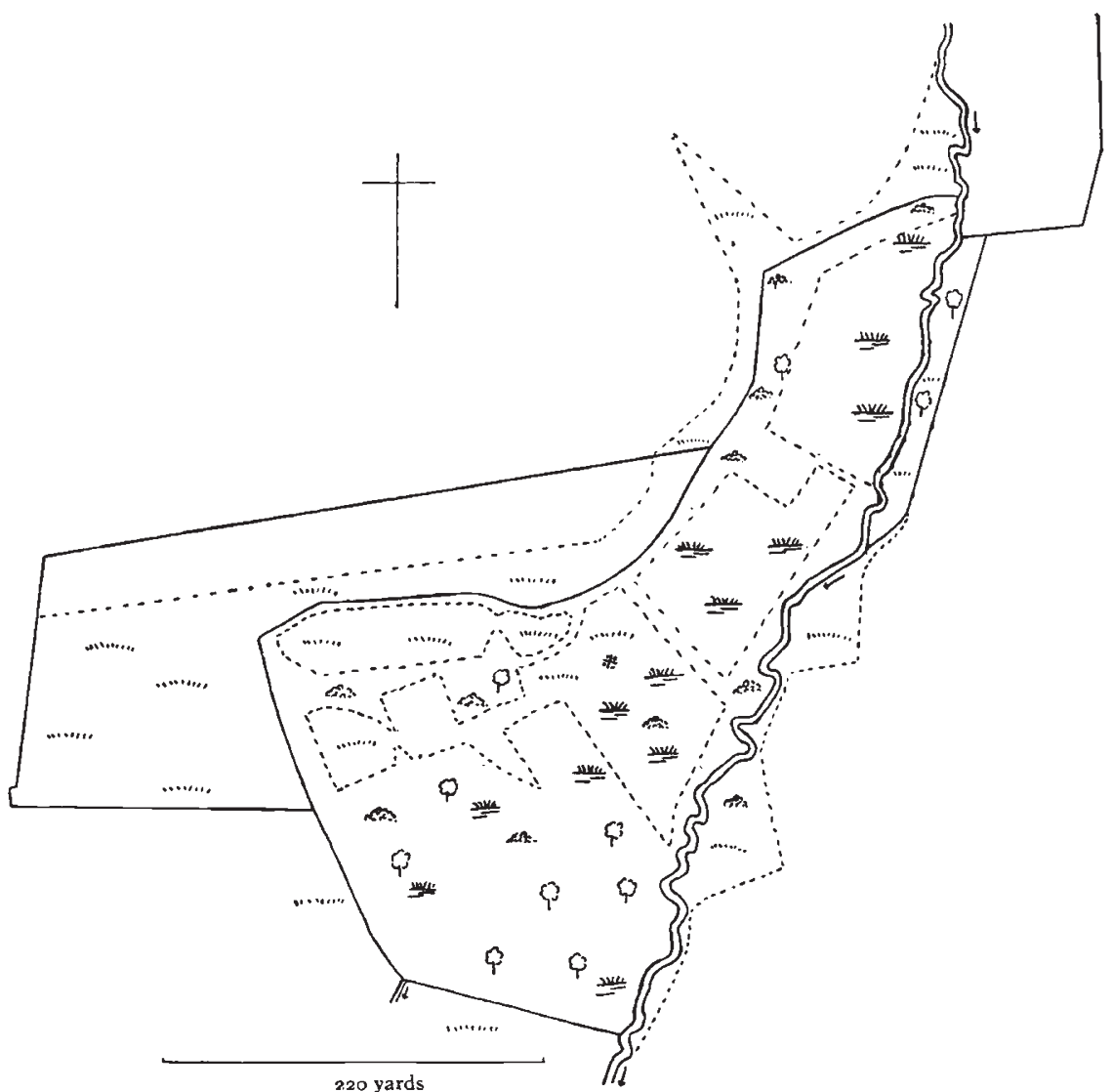

FIG. 1.-In the sketch map of Sheepstead Hurst, the peat workings in the wood are indicated by a broken line. Panaxia dominula is common in all areas of the colony except the southern wooded part.

$*$ = releasing point.

are confined to these workings and Hemp Agrimony (Eupatorium cannabinum L.) to the thin areas of wood which separate them. The locality in which the new population lives is more wooded and damper than that at Cothill, which was described by Fisher and Ford (1947), but covers about the same area (approximately twenty acres in all (fig. I).

Since I 946 certain changes, which are worth recording, have 
taken place in the Cothill colony. The wood between $\mathbf{B}$ and $\mathbf{E}$ (see Fisher and Ford, 1947, fig. I) was felled in 1947 and new scrub about six feet high is growing up from the old stools. $P$. communis is extending its range from area $B$ and is now to be found in the north-west corner of $\mathrm{A}$ as well as in large quantities in the rectangular field north of B and D. It has also increased in abundance in area D. The distribution of $P$. dominula in the colony has changed quite markedly in the last four seasons, almost certainly as the result of changes in the distribution of the reeds. The moth is not now found at all in area $\mathbf{E}$ and is not nearly so common as it used to be in area $\mathbf{C}$. However, it is common among the reeds and has extended its range up to the limits of the ground occupied by $P$. communis in the rectangular field north of $\mathrm{B}$ and $\mathrm{D}$. It is also very abundant among the reeds in the north-east corner of area $\mathrm{D}$ as well as being not uncommon as far as the middle of this field.

\section{THE Selective VALUe OF tHe medionigra gene AT COTHILL}

Fisher and Ford (1947) showed that the fluctuations in the frequency of the medionigra gene between 1939 and 1946 could not be due to "genetic drift." However, because of the short period over which the observations were made, they were unable to observe any marked trend in the change of gene frequency. They concluded that the selective value of the gene was probably fluctuating from year to year and that the heterozygote was at an advantage to both homozygotes. With the additional information obtained since 1946 it is possible to see that there is a decided trend in the change of gene frequency. Moreover, because there is no dominance it is possible to estimate the relative selective advantages of all three genotypes. It has been shown by Hardy (rgo8) that in an infinite bisexually reproducing population, mating at random, where the two allelomorphs of a gene, that is not sex-linked, are in the ratio of $p: q$, the ratio of the genotypes in the next generation is $p^{2}: 2 p q: q^{2}$, where $p^{2}$ and $q^{2}$ are the two homozygotes. However, if the selective advantage of the three genotypes is in the ratio of $\mathrm{I}: b: c$ the genotypes will have the frequency $p^{2}: 2 b p q: c q^{2}$. Consequently, if the proportions of the two allelomorphs are known, the selective advantage of the three genotypes can be estimated. Ignoring, for the moment, the fact that the population at Cothill is not infinite but is of known size, greater than a thousand individuals, and also ignoring sampling errors in estimating the gene frequency and the ratio of the three genotypes in any season, it is possible to calculate the selective values of the three genotypes for the years $194^{\circ}$ to $195^{\circ}$. If the number of individuals in each genotype is $\mathrm{H} c$ for the common homozygote, in this instance dominula; $\mathrm{Hz}$ for the heterozygote medionigra; $\mathrm{Hr}$ for the rare homozygote bimacula and $p$ represents the normal gene and $q$ its allelomorph, 
in the preceding generation, then $\mathrm{H} c$ is proportional to $p^{2}, \mathrm{~Hz}$ to $2 b p q$ and $\mathrm{Hr}$ to $c q^{2}$. It follows that :-

$$
b=\frac{\mathrm{H} z p}{2 \mathrm{H} c q}, \quad c=\frac{H r p^{2}}{\mathrm{H} c q^{2}} \quad \text { and } \quad \frac{b}{c}=\frac{\mathrm{H} z q .}{2 \mathrm{H} r p}
$$

Table 3 gives the values of $b$ and $c$ for the different years using the gene ratios obtained by sampling the population (table 4 ). Fisher and

TABLE 3

\begin{tabular}{|c|c|c|}
\hline Year & $\begin{array}{c}\text { Selective value of } \\
\text { medionigra }\end{array}$ & $\begin{array}{c}\text { Selective value of } \\
\text { bimacula }\end{array}$ \\
\hline 1940 & $1 \cdot 29$ & $1 \cdot 06$ \\
1941 & 0.59 & 0.32 \\
1942 & 0.82 & $\ldots$ \\
1943 & $1 \cdot 11$ & $\ldots$ \\
1944 & 0.81 & 0.63 \\
1945 & $1 \cdot 42$ & $2 \cdot 72$ \\
1946 & 0.62 & 0.70 \\
1947 & 0.85 & $1 \cdot 22$ \\
1948 & 0.96 & 0.74 \\
1949 & 0.82 & $\ldots$ \\
1950 & $1 \cdot 35$ & $\cdots$ \\
\hline
\end{tabular}

TABLE 4

\begin{tabular}{|c|c|c|c|c|c|}
\hline Year & dominula & medionigra & bimacula & Total & $\begin{array}{c}\text { Gene-frequency } \\
\text { per cent. }\end{array}$ \\
\hline $\mathrm{U}_{\mathrm{p}}$ to 1928 & 164 & 4 & o & 168 & $x \cdot 2$ \\
\hline 1939 & 184 & 37 & 2 & 223 & $9 \cdot 2$ \\
\hline 1940 & 92 & 24 & I & 117 & $I I \cdot I$ \\
\hline 1941 & 400 & 59 & 2 & $46 x$ & $6 \cdot 8$ \\
\hline 1942 & 183 & 22 & o & 205 & $5 \cdot 4$ \\
\hline 1943 & 239 & 30 & o & 269 & $5 \cdot 6$ \\
\hline 1944 & 452 & 43 & I & 496 & $4 \cdot 5$ \\
\hline 1945 & 326 & 44 & 2 & 372 & $6 \cdot 5$ \\
\hline 1946 & 905 & 78 & 3 & 986 & $4 \cdot 3$ \\
\hline $\begin{array}{l}1947 \\
1948\end{array}$ & $\begin{array}{r}1244 \\
898\end{array}$ & $\begin{array}{l}94 \\
67\end{array}$ & $\begin{array}{l}3 \\
1\end{array}$ & $\begin{array}{r}134 I \\
966\end{array}$ & $\begin{array}{l}3 \cdot 7 \\
3 \cdot 6\end{array}$ \\
\hline 1949 & 479 & 29 & 0 & 508 & $2 \cdot 9$ \\
\hline \multirow[t]{2}{*}{1950} & I 106 & 88 & o & 1194 & \multirow[t]{2}{*}{$3 \cdot 7$} \\
\hline & 6508 & 615 & 15 & $7^{1} 3^{8}$ & \\
\hline
\end{tabular}

Ford (1947) point out that no simple relationship exists between population size each season and the frequency of the medionigra gene. They suggest that the fluctuations in population size from season to season may be an expression of changes in the direction and intensity of selection. It can be seen that population size can change in a regular manner without a change in the environment and, similarly, the gene frequency can also change regularly. Consequently, if changes in population size are the result of alterations in the direction 
and intensity of selection it is necessary to compare change in the rate of change of population size with change in selective advantage. Unfortunately, the estimates of seasonal population size and selective value of medionigra are only tentative and therefore little reliance can be placed on such a comparison. However, change in population size, on a logarithmic scale, has been plotted on the same graph as selective advantage of var. medionigra (fig. 2). The slope of the lines

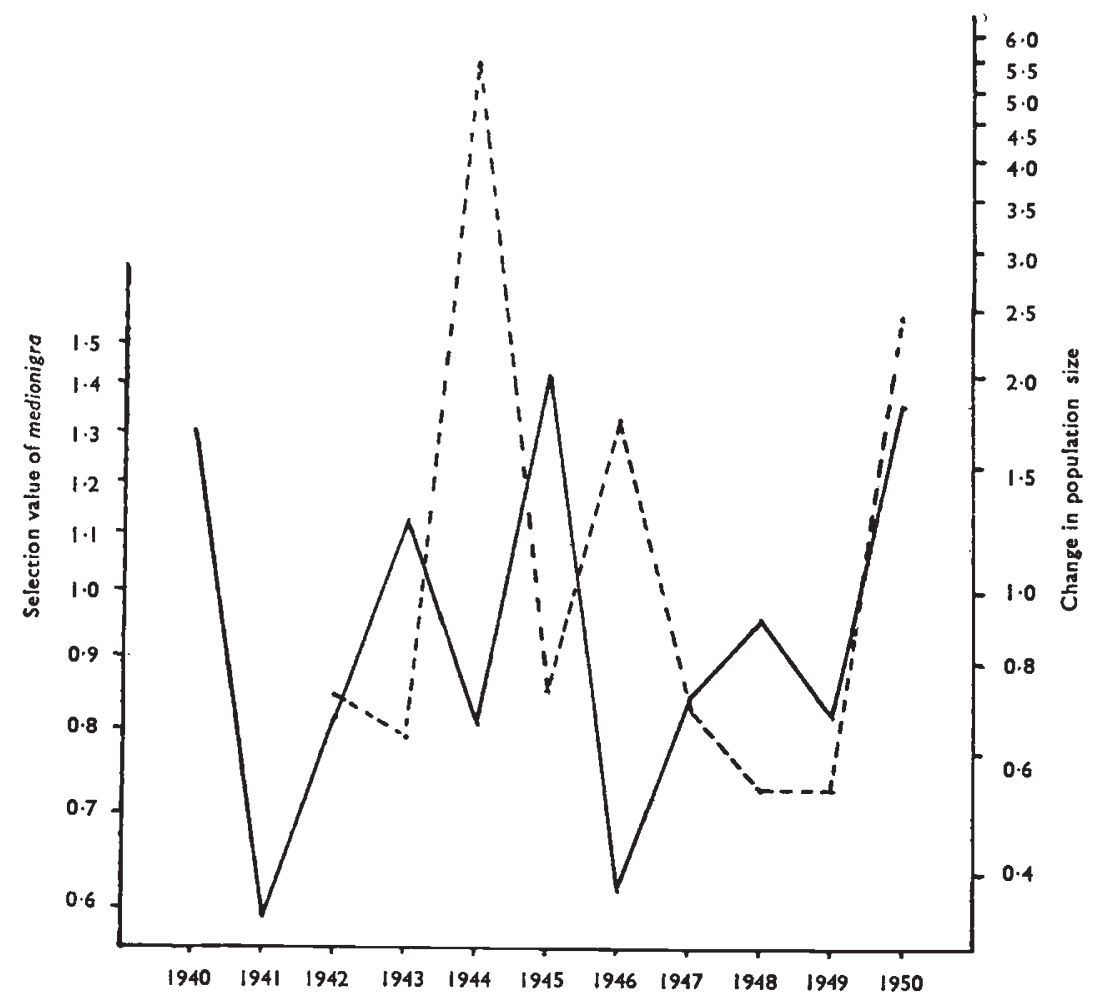

Fig. 2.-In the graph, change of population size is plotted on a logarithmic scale and the slope of the line indicates change in the rate of change of population size. The slope of the continuous line gives the change in the selective advantage of var. medionigra.

which indicates change in rate of change of population size and gene frequency go in opposite directions on six out of eight occasions. If there is an equal chance of them sloping either way and it is of equal interest if they always tend to go in the same or opposite directions, the probability of this result being obtained by chance is greater than 0.05 and therefore does not reach the formal significance level. It is possible to make an independent test to ascertain if there is any evidence that the relative selective values of the three genotypes are fluctuating. If the values of $b$ and $c$ are constant it is possible to calculate the expected gene frequency from year to year. The homozygote bimacula is rare and therefore makes 
little difference to the gene frequency. Consequently, we may assume that the value of $c$ is the same as $b^{2}$. From this it follows that the percentage of the gene frequency of the dominula gene is $\frac{100 p}{p+b q}$, if the ratio of the two allelomorphs in the previous generation is $p: q$.

This simplification makes it possible to use the maximum likelihood method to fit a regression line. If there is no evidence of heterogeneity

TABLE 5

\begin{tabular}{|c|c|c|c|}
\hline Year & $\begin{array}{l}\text { Expected number of } \\
\text { dominula genes }\end{array}$ & $\begin{array}{l}\text { Expected number of } \\
\text { medionigra genes }\end{array}$ & $x^{2}$ \\
\hline \multirow[t]{2}{*}{$\begin{array}{l}1939 \\
1940 \\
1941 \\
1942 \\
1943 \\
1944 \\
1945 \\
1946 \\
1947 \\
1948 \\
1949 \\
1950\end{array}$} & \multirow[t]{2}{*}{$\begin{array}{r}408 \cdot 1 \\
215 \cdot 8 \\
856 \cdot 5 \\
383 \cdot 4 \\
506 \cdot 2 \\
938 \cdot 5 \\
707 \cdot 4 \\
1883 \cdot 6 \\
2572 \cdot 6 \\
1860 \cdot 2 \\
981 \cdot 6 \\
2314 \cdot 5\end{array}$} & \multirow[t]{2}{*}{$\begin{array}{r}37 \cdot 9 \\
18 \cdot 2 \\
65 \cdot 5 \\
26 \cdot 6 \\
31 \cdot 8 \\
53 \cdot 5 \\
36.6 \\
88.4 \\
109.4 \\
71 \cdot 8 \\
34.4 \\
73 \cdot 5\end{array}$} & $\begin{array}{l}0.27 \\
3.62 \\
0.11 \\
0.86 \\
0 \cdot 11 \\
1.43 \\
3.73 \\
0.23 \\
0.84 \\
0.11 \\
0.88 \\
2.95\end{array}$ \\
\hline & & & $15 \cdot 14 n=10$ \\
\hline
\end{tabular}

TABLE 6

\begin{tabular}{|c|c|c|c|c|}
\hline Year & $\begin{array}{c}\text { Expected number of } \\
\text { dominula }\end{array}$ & $\begin{array}{l}\text { Expected number of } \\
\text { medionigra }\end{array}$ & $\begin{array}{c}\text { Expected number of } \\
\text { bimacula }\end{array}$ & Total \\
\hline \multirow[t]{2}{*}{$\begin{array}{l}1939 \\
1940 \\
1941 \\
1942 \\
1943 \\
1944 \\
1945 \\
1946 \\
1947 \\
1948 \\
1949 \\
1950\end{array}$} & $\begin{array}{r}186.7 \\
99^{\circ} 5 \\
397.9 \\
179 \cdot 3 \\
23^{\circ} \cdot 1 \\
443^{\circ} 9 \\
33^{\circ} \cdot 3 \\
899^{\circ} 6 \\
1233^{\circ} 8 \\
895^{\circ} 6 \\
474^{\circ} \cdot 2 \\
1121.7\end{array}$ & $\begin{array}{r}34.7 \\
16 \cdot 8 \\
60 \cdot 7 \\
24 \cdot 8 \\
30 \cdot 0 \\
50.7 \\
34 \cdot 8 \\
84 \cdot 4 \\
105 \cdot 0 \\
69 \cdot 0 \\
33 \cdot 2 \\
71 \cdot 1\end{array}$ & $\begin{array}{l}1 \cdot 6 \\
0 \cdot 7 \\
2 \cdot 4 \\
0 \cdot 9 \\
0 \cdot 9 \\
1 \cdot 4 \\
0 \cdot 9 \\
2 \cdot 0 \\
2 \cdot 2 \\
1 \cdot 4 \\
0 \cdot 6 \\
1 \cdot 2 \\
\end{array}$ & $\begin{array}{r}223 \\
117 \\
461 \\
205 \\
269 \\
496 \\
372 \\
986 \\
1341 \\
966 \\
508 \\
1194 \\
\end{array}$ \\
\hline & $6_{5} 06 \cdot 6$ & $615 \cdot 2$ & 16.2 & 7138 \\
\hline
\end{tabular}

in the data, it is unnecessary to vary the value of $c$ to improve the fit. The expected number of medionigra for the different years is given in table 6 . The method gives a good estimate of the value of $b$ as well as the gene frequency in any year. The value of $b$ is 0.907 that is a selective disadvantage of the heterozygotes of about ro per cent. The observed frequencies of the medionigra gene together with its expected frequencies are plotted in fig. 3. The $\chi^{2}$ for heterogeneity is 15.14 with 10 degrees of freedom which gives $P>0 \cdot 10$. It follows 
that there is no evidence that the relative selective advantages of the three genotypes are not constant. The expected number of bimacula for the years 1939 to 1950 is 16.2 , whereas the observed number is 15 . This is so close to expectation that it is unnecessary to readjust the value of $c$ in order to give a better fit (tables 5 and 6).

The selective value of medionigra is particularly interesting not only on account of the increase in frequency of the gene between 1928 and 1939, but also because no marked differential viability between

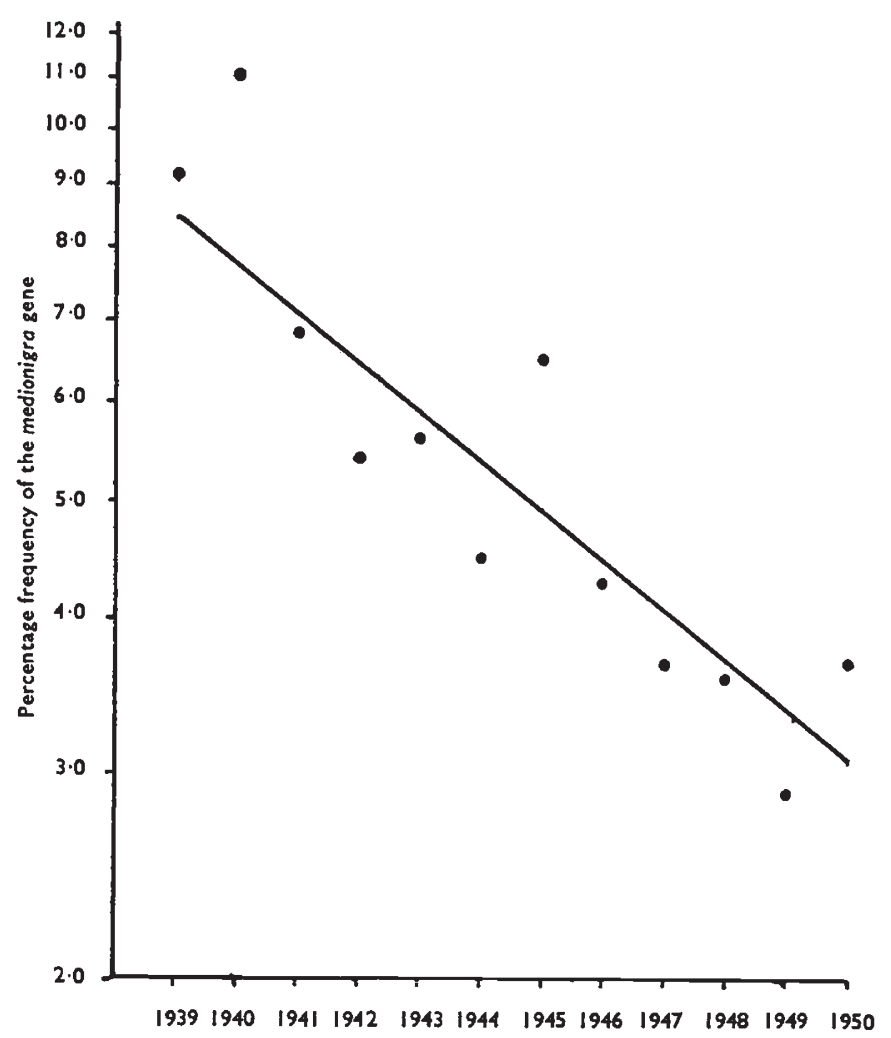

FIg. 3. - In the diagram the observed frequency of the medionigra gene is plotted on a logarithmic scale. The regression line has been fitted by assuming that the selective value of the three genotypes are constant.

dominula and medionigra, the heterozygote, has ever been observed in the laboratory. Fisher and Ford compared the date of first capture of insects carrying the variant gene and those not carrying it, and found that there was no significant difference between the two. The method they employed has been used to make the same comparison for the seasons 1947, 1948, 1949 and 1950 (table 7). Again there is no evidence of a difference in date of first capture of insects of different genotypes. A further comparison can be made between the behaviour of typical dominula and var. medionigra. The ratio of the two types released on any day is known as well as their proportions on recapture 
on subsequent days. It is therefore possible to compare the expected and observed number of recaptures of the two types (table 8). Although the $\chi^{2}$ for the difference reaches the formal level of significance in 1947 $(\mathbf{P}<0.05)$, it is not maintained in the other seasons and over the years I 947 to $195^{\circ}$. The data do not indicate a difference between expected and observed recaptures of individuals carrying the medionigra gene.

TABLE 7

\begin{tabular}{|c|c|c|c|c|c|}
\hline Year & $\begin{array}{c}\text { Normal gene } \\
\text { July }\end{array}$ & $\begin{array}{c}\text { medionigra gene } \\
\text { July }\end{array}$ & Difference & & $\chi_{\mathbf{2}}$ \\
\hline & - & 19.701 & -0.671 & earlier & $\begin{array}{l}0.1763 \\
1947\end{array}$ \\
1948 & 20.372 & 20.647 & +0.105 & later & 0.0387 \\
1949 & 17.115 & 15.897 & -1.218 & earlier & 1.2358 \\
1950 & 19.719 & 20.409 & +0.690 & later & 0.7777 \\
\hline
\end{tabular}

TABLE 8

\begin{tabular}{|c|c|c|c|c|c|}
\hline \multirow{2}{*}{ Year } & \multicolumn{2}{|c|}{ Recaptures of dominula } & \multicolumn{2}{|c|}{ Recaptures of medionigra } & \multirow{2}{*}{ Totals } \\
\hline & Expected & Observed & Expected & Observed & \\
\hline $\begin{array}{l}1947 \\
194^{\circ} \\
1949 \\
195^{\circ}\end{array}$ & $\begin{array}{l}230 \cdot 04 \\
270 \cdot 41 \\
160 \cdot 51 \\
407 \cdot 74\end{array}$ & $\begin{array}{l}239 \\
270 \\
163 \\
405\end{array}$ & $\begin{array}{l}15.96 \\
17.59 \\
10.49 \\
31 \cdot 26\end{array}$ & $\begin{array}{r}7 \\
18 \\
8 \\
31\end{array}$ & $\begin{array}{l}246 \\
288 \\
171 \\
439\end{array}$ \\
\hline
\end{tabular}

No medionigra or bimacula have been observed at Sheepstead Hurst. Thus it is certain that the frequency of the medionigra gene is different in the two populations and the gene is probably absent from the new colony. This is important, not only in the light of the other differences between the two breeding-communities, but also because it indicates that there is not a large amount of migration from Cothill to Sheepstead Hurst. Half the moths marked in the new colony were given a distinctive spot and none has ever been recaptured at Cothill, so that migration in the opposite direction is also not very common if it occurs at all. Consequently, it can be said with some certainty that the two populations are well isolated by the agricultural land between them.

The new form of dominula (var. A) is found in both colonies and the percentage of this form at Cothill and Sheepstead Hurst from year to year is given in table 9. Not enough information is available to say anything except that the percentage of var. A at Cothill is much lower than in the other colony. The proportion of this form at Cothill increased between 1948 and 1949 and decreased again in r950, it also decreased significantly between I 949 and 1950 at Sheepstead Hurst. This difference between the colonies is genetic although it may also be environmental. The environment, as far as it affects 
the ecology of $P$. dominula in the two colonies, is different. This is clearly shown by the increase in population size at Cothill between I 949 and $195^{\circ}$ and the decrease in the other colony over the same period. Moreover, there is apparently a difference in the death-rate

TABLE 9

\begin{tabular}{|c|c|c|c|c|c|c|}
\hline \multirow{2}{*}{ Year } & \multicolumn{3}{|c|}{ Cothill } & \multicolumn{3}{|c|}{ Sheepstead Hurst } \\
\hline & Var. A & Total & $\begin{array}{c}\text { Per cent. } \\
\text { var. A }\end{array}$ & Var. A & Total & $\begin{array}{c}\text { Per cent. } \\
\text { var. A }\end{array}$ \\
\hline $\begin{array}{l}194^{8} \\
1949 \\
1950\end{array}$ & $\begin{array}{l}21 \\
23 \\
26\end{array}$ & $\begin{array}{r}966 \\
508 \\
1194\end{array}$ & $\begin{array}{l}2 \cdot 2 \\
4 \cdot 5 \\
2 \cdot 2\end{array}$ & $\begin{array}{l}88 \\
66\end{array}$ & $\begin{array}{l}528 \\
935\end{array}$ & $\begin{array}{r}16 \cdot 7 \\
7 \cdot I\end{array}$ \\
\hline
\end{tabular}

of adults in the two colonies although it is not known whether this is significant as it has, so far, been impossible to assign a standard error to the death-rate. Furthermore, in the early part of May I950, random samples of larvæ were taken from both colonies and the proportion of caterpillars in their last instar in the two populations was found to differ significantly (table Io). This effect is almost

TABLE IO

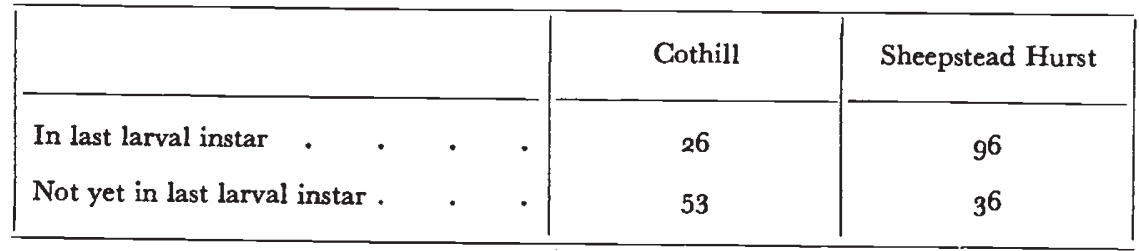

certainly environmental as stocks from the two localities reared in constant conditions in the laboratory showed no difference in the time at which they reached the last larval instar. There is therefore a real distinction between the environment in the two areas although they are close together and similar in general features. Seven examples of a pale orange hind-winged form of $P$. dominula have been found at Cothill since 1947 but neither the $F_{1}$ generation of one of these moths which paired with a normal form nor the $F_{2}$ have produced any examples of this orange variety. Kettlewell (personal communication) has been unable to demonstrate that pink or orange hind-winged varieties of this moth are the result of inherited factors. None of these aberrant individuals has been found at Sheepstead Hurst.

\section{THE ESTIMATION OF DAILY AND SEASONAL POPULATION SIZE}

To obtain an estimate of daily population size in the two localities, a sample of insects was collected each day. To ensure that this was random, equal areas of the colonies were collected in for equal periods 
of time, and all the moths that could be caught were placed in separate boxes and kept until the whole sample had been taken. Each insect was then marked by the method developed by Dowdeswell, Fisher and Ford (1940) using a spot of quick drying cellulose paint which is waterproof and permanent. By varying the colour and position of the mark, it was possible to leave a permanent record on each insect of how many times and on what dates it had been captured. Any individuals which were obviously damaged were killed and recorded as having been killed. All other moths were taken to a central releasing point and were thrown, one at a time, high into the air. Most of them took to the wing and could be seen flying away into the colony. The few moths that failed to fly outside an arbitrary distance of ten yards were again thrown into the air and if they still did not fly they were left until next day. In the morning this area of ten yards radius was carefully searched and any marked insects in it, which still would not fly, were killed, and recorded as having been killed on the date they were captured. Furthermore, no sampling was ever carried out in this releasing area. This ensures that no insects which had been damaged and therefore were incapable of distributing themselves at random in the population were released. Further details of this technique and of the method of estimating population size have been given by Fisher and Ford (1947) and will therefore be only summarily dealt with here. From a knowledge of the time interval between release and recapture of moths recaptured on a particular day it is possible to estimate the death-rate of adults, providing it is assumed that it is a constant. In fact, no significant departure from a constant death-rate could be detected. Fisher and Ford (1947) estimated the best possible death-rate for the years I 94 I to 1945 and used it to determine the number of marks carried by insects in the population from day to day. If this is known, then from a knowledge of the number of insects caught on any one day and the number of marks they carry between them, it is possible to estimate the daily population size.

There is no reason to suppose the death-rate in the Sheepstead Hurst colony to be the same as that at Cothill or that it is the same from year to year. Consequently, in this paper, separate death-rates have been estimated for both sexes and both colonies in each successive year. Table I I gives the death-rate of insects in the Cothill population for the years 1947 to $195^{\circ}$ and in the Sheepstead Hurst colony for 1949 and 1950 as well as the death-rates for both sexes. It will be seen that the estimated expectation of life of females is higher than that of the males in both colonies in 1949 and 1950 , and this difference in the new colony in 1949 is large. Also the best estimate of death-rate of each sex in this population has always been lower than that for the corresponding sex in the Cothill colony. An independent check on the difference between the death-rates of the sexes can be obtained by a comparison of the observed and expected number of marks 
carried by males and females recaptured on any date. The expected ratio of marks between the sexes among recaptures can be obtained from the estimated number of marks carried by each sex in the population on that day. This ratio may be upset if one sex is more readily captured than the other. A comparison of the results for

TABLE II

\begin{tabular}{|c|c|c|c|}
\hline Year & Locality & Sex & Daily survival rate \\
\hline I 947 & Cothill & males and females & 0.755 \\
\hline 1948 & , & males and females & 0.729 \\
\hline 1949 & , & males and females & 0.645 \\
\hline I 949 & ," & males & 0.587 \\
\hline I 949 & ", & females & 0.670 \\
\hline 1949 & Sheepstead Hurst & males and females & 0.722 \\
\hline I 949 & $"$ & males & 0.600 \\
\hline I 949 & G.', & females & 0.804 \\
\hline $195^{\circ}$ & Cothill & males and females & 0.762 \\
\hline 1950 & ," & males & $0 \cdot 757$ \\
\hline $195^{\circ}$ & ", & females & 0.777 \\
\hline $195^{\circ}$ & Sheepstead Flurst & males and females & 0.806 \\
\hline I $95^{\circ}$ & , $\quad$ " & males & 0.796 \\
\hline $195^{\circ}$ & , & females & 0.829 \\
\hline $195^{\circ}$ & $\begin{array}{l}\text { Sheepstead Hurst } \\
\text { (without extra mark) }\end{array}$ & males and females & 0.801 \\
\hline 1950 & $\begin{array}{l}\text { Sheepstead Hurst } \\
\text { (with extra mark) }\end{array}$ & males and females & 0.811 \\
\hline
\end{tabular}

I949 and 1950 (table 12) shows that the use of a larger death-rate for males has improved the fit three out of four times and that even at Sheepstead Hurst in I950 when there was no improvement, the difference is not nearly significant. In I 949 the difference in the

TABLE I 2

\begin{tabular}{|c|c|c|c|c|c|}
\hline \multirow{2}{*}{ Year } & \multirow{2}{*}{ Locality } & \multicolumn{2}{|c|}{ Recaptures of females } & \multicolumn{2}{|c|}{ Recaptures of males } \\
\hline & & Expected & Observed & Expected & Observed \\
\hline $\begin{array}{l}1949 \\
1950 \\
1949 \\
1950\end{array}$ & $\begin{array}{l}\text { Cothill } \\
\text {," } \\
\text { Sheepstcad Hurst } \\
\text {," , }\end{array}$ & $\begin{array}{r}101 \cdot 54 \\
195 \cdot 43 \\
47 \cdot 14 \\
88 \cdot 45\end{array}$ & $\begin{array}{r}\text { I I } 4 \\
\text { 1 } 99 \\
43 \\
75\end{array}$ & $\begin{array}{r}69 \cdot 46 \\
243.57 \\
25 \cdot 86 \\
149.55\end{array}$ & $\begin{array}{r}57 \\
240 \\
30 \\
163\end{array}$ \\
\hline
\end{tabular}

estimated death-rate of males and females in this colony was large. Moreover, if the same daily survival value of 0.722 is used for both sexes when calculating the expected number of recaptures among males and females, a significant discrepancy between the expected and observed recaptures is obtained. Furthermore, at Cothill in 1949 there is still a large difference between the expected and observed number of recaptures of the two sexes even when the best estimates of daily elimination are used. This evidence strongly suggests that the death-rates of males and females were not the same in 1949. 
Before discussing daily and seasonal population sizes it is necessary to consider the effect of the mark on the expectation of life of the insect carrying it. If the expectation of life of moths carrying a mark is different from those not carrying it, the calculation of daily population size will not be appreciably affected because the estimated death-rate is only used to calculate the number of marks carried by insects in the population. However, the seasonal population size will be affected as its calculation must be based on the total number of emergences, which can only be estimated from a knowledge of the death-rate of all the insects in the colony. The effect of marking was tested at Sheepstead Hurst in 1949 and 1950. Approximately half the moths were marked in the usual way and the other half were given an extra mark which was put on the white central spot on the fore-wing (a position never used for date marks). The extra marks were of two types in equal proportions, one white and one blue. The white mark which is on a normally white area, could not be readily seen even on an insect at rest. Precautions were taken to ensure that insects chosen for double marking were taken at random. Boxes containing all the insects which had not been previously marked were placed in a pile, and divided into equal heaps, and one of these was again divided. From these two small piles one was chosen at random and the moths in these boxes received an extra blue mark, whereas those in the other small pile were given an extra white mark. The expected and observed number of recaptures of single and double marked individuals in 1949 and $195^{\circ}$ is given in table 13. It will

TABLE 13

\begin{tabular}{|c|c|c|c|c|c|c|}
\hline \multirow{2}{*}{ Year } & \multicolumn{2}{|c|}{ No extra mark } & \multicolumn{2}{|c|}{ Extra white mark } & \multicolumn{2}{|c|}{ Extra blue mark } \\
\hline & Expected & Observed & Expected & Observed & Expected & Observed \\
\hline $\begin{array}{l}1949 \\
1950\end{array}$ & $\begin{array}{r}32 \cdot 39 \\
101 \cdot 88\end{array}$ & $\begin{array}{l}33 \\
85\end{array}$ & $\begin{array}{l}15 \cdot 82 \\
51 \cdot 71\end{array}$ & $\begin{array}{l}16 \\
67\end{array}$ & $\begin{array}{l}15 \cdot 79 \\
52 \cdot 4^{I}\end{array}$ & $\begin{array}{l}\text { I5 } \\
54\end{array}$ \\
\hline
\end{tabular}

be seen that the observed number of recaptures is very close to its expectation in 1949. However, in 1950 a significant excess of double marked individuals was recaptured. The death-rates of double and single marked moths are given in table I I and are obviously not significantly different. Moreover, the discrepancy between the observed and expected number of recaptures among double marked insects cannot be the result of the observed difference in the daily survival rate of the two types, because it would have to be much larger to account for the disagreement. An alternative explanation is that insects carrying the extra mark are easier to recapture than those not carrying it. Nevertheless, this cannot be 
the result of a decrease in the effectiveness of the protective colouration because insects carrying a white mark, which cannot be seen except after close examination, are recaptured as often as those bearing a distinctive blue one. It is therefore probable that the mechanical effect of a small spot of paint on the wings makes the moths easier to catch when flying. This can be tested next season by recording which insects are captured at rest and in flight (see Note p. 378). It is of interest that no discrepancy between the two types of individuals was detected in 1949, when, because of the hot season, the moths were particularly active. The death-rate of adults is known and therefore the frequency of recapture of insects marked more than once in the Cothill population can be examined. This can be done by estimating the number of insects bearing one, two, three and four marks in the population on any day and comparing it with the proportion of these types among recaptures (table 14).

TABLE 14

\begin{tabular}{|c|c|c|c|c|c|c|c|c|}
\hline \multirow{2}{*}{ Year Locality } & \multicolumn{2}{|c|}{ I mark } & \multicolumn{2}{|c|}{2 marks } & \multicolumn{2}{|c|}{3 marks } & \multicolumn{2}{|c|}{4 or more marks } \\
\hline & Expected & Observed & Expected & Observed & Expected & Observed & Expected & Observed \\
\hline \multirow[t]{2}{*}{$\begin{array}{l}\text { I947 Cothill } \\
\text { I948 Cothill } \\
\text { I949 Cothill } \\
\text { I950 Cothill }\end{array}$} & $\begin{array}{l}182 \cdot 42 \\
187.43 \\
105.90 \\
273 \cdot 51\end{array}$ & $\begin{array}{l}\text { I } 76 \\
\text { I } 89 \\
\text { I I I } \\
279\end{array}$ & $\begin{array}{l}22 \cdot 45 \\
37 \cdot 75 \\
20 \cdot 64 \\
62 \cdot 45\end{array}$ & $\begin{array}{l}26 \\
43 \\
29 \\
60\end{array}$ & $\begin{array}{r}2 \cdot 60 \\
10 \cdot 18 \\
6 \cdot 38 \\
12 \cdot 18\end{array}$ & $\begin{array}{r}6 \\
3 \\
4 \\
12\end{array}$ & $\begin{array}{l}0.53 \\
0.64 \\
1.08 \\
3.86\end{array}$ & $\begin{array}{l}0 \\
1 \\
0 \\
1\end{array}$ \\
\hline & $749 \cdot 26$ & 745 & 143.29 & I $5^{8}$ & $31 \cdot 34$ & 25 & $6 \cdot I I$ & 2 \\
\hline
\end{tabular}

Although the data give an indication that there may be a decrease in the expectation of life with an increase in age it will not be large enough to materially alter the estimated population sizes. On the other hand, there seems no very compelling reason for believing that marking increases the ease of recapture. However, even if this were so, Fisher and Ford's conclusions that the fluctuations in the gene frequency of the medionigra gene cannot be due to chance, will not be invalidated because their estimated seasonal population sizes will be too small and not too large. Until more data are available, it may be tentatively assumed that marking does not markedly increase the ease with which the insect may be captured. Tables 15 to 26 give all the information necessary for calculating death-rates and population size. This type of table has not been used before and therefore requires some explanation. It is divided into vertical columns each headed by the appropriate date. At their foot will be found the number of moths caught and released each day. The numbers in the body of the table refer to the number of marks retaken at varying intervals of time after first capture. The date to which each refers is given at the 
TABLE I5

Cothill. Males and females

July 1947

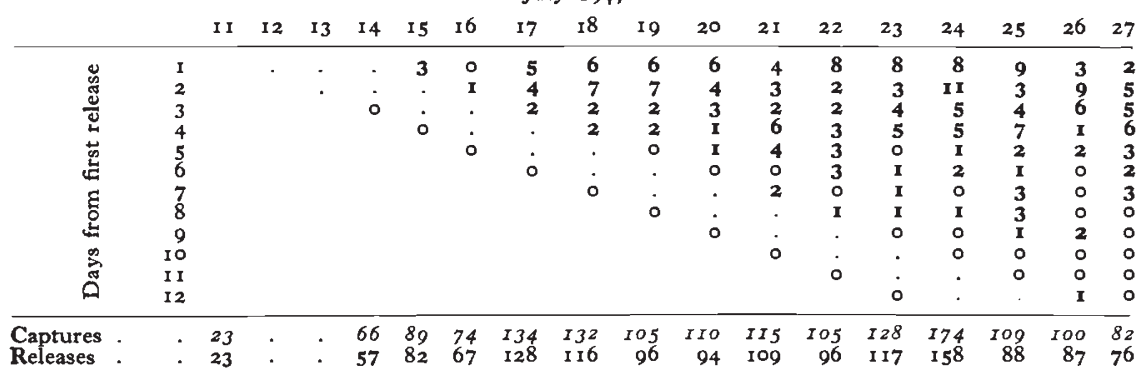

TABLE I 6

Cothill. Males and females

July 1948

$\begin{array}{lllllllllllllllllllllllllll}5 & 6 & 7 & 8 & 9 & 10 & 11 & 12 & 13 & 14 & 15 & 16 & 17 & 18 & 19 & 20 & 21 & 22 & 23 & 24 & 25 & 26 & 27 & 28 & 29 & 30 & 31\end{array}$

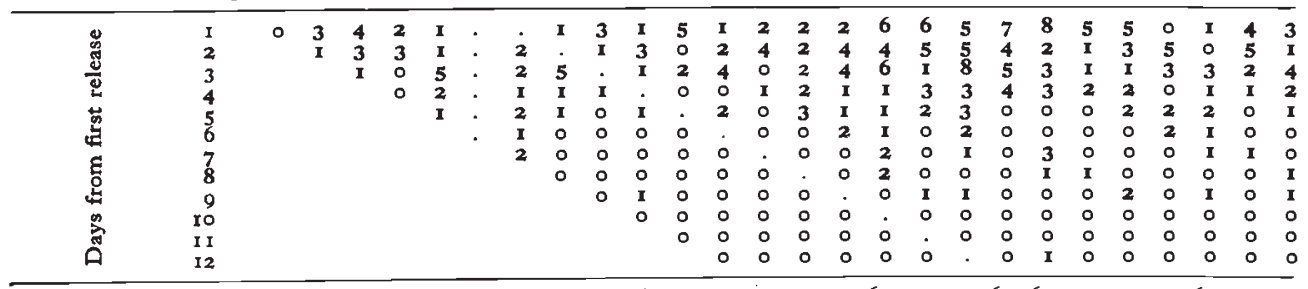
\begin{tabular}{llllllllllllllllllllllllllllll}
\hline Captures &. &. & 2 & 19 & 24 & 31 & 27 & 34 &. & 28 & 40 & 31 & 46 & 34 & 35 & 52 & 51 & 72 & 67 & 75 & 94 & 69 & 64 & 51 & 44 & 45 & 63 & 59 & 45 \\
Releases &. &. & 2 & 17 & 23 & 30 & 24 & 33 &. & 27 & 40 & 29 & 44 & 32 & 34 & 49 & 46 & 70 & 59 & 67 & 88 & 67 & 60 & 47 & 39 & 39 & 60 & 56 & 42
\end{tabular}

TABLE I 7

Cothill. Males

July 1949

\begin{tabular}{|c|c|c|c|c|c|c|c|c|c|c|c|c|c|c|c|c|c|c|c|c|c|c|c|c|c|c|}
\hline & 3 & 4 & 5 & 6 & 7 & 8 & 9 & I0 & I I & I 2 & 13 & 14 & I5 & I6 & 17 & I 8 & 19 & 20 & 21 & 22 & 23 & 24 & 25 & 26 & 27 & 28 \\
\hline \multirow{8}{*}{ 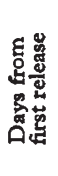 } & I & . & . & . & . & 0 & 2 & $\mathbf{I}$ & I & 0 & 0 & 2 & I & 2 & 2 & 0 & 0 & 3 & 2 & $\mathbf{I}$ & $\mathbf{I}$ & $\mathbf{I}$ & $\mathbf{I}$ & $\mathbf{I}$ & . & \\
\hline & 2 & & 0 & . & 0 & . & $\overline{\mathbf{I}}$ & 0 & I & 0 & I & 0 & $\mathbf{I}$ & I & 0 & 3 & $\mathbf{I}$ & 0 & 2 & I & 0 & $\mathbf{I}$ & $\mathbf{I}$ & I & . & 0 \\
\hline & 3 & & & . & . & 0 & . & $\mathbf{I}$ & 0 & 0 & 2 & I & 0 & $\mathbf{I}$ & 0 & 2 & $\mathbf{I}$ & 0 & 2 & 0 & 2 & 0 & 0 & 0 & . & 0 \\
\hline & 4 & & & & 0 & . & 0 & . & 0 & 0 & I & I & 0 & 0 & 0 & 0 & 0 & 2 & 0 & 0 & 0 & 0 & 0 & 0 & . & 0 \\
\hline & 5 & & & & & 0 & . & 0 & . & 0 & 0 & 0 & 0 & I & 0 & 0 & 0 & 0 & 0 & 0 & 0 & 0 & 0 & 0 &. & 0 \\
\hline & 6 & & & & & & 0 & . & 0 & & 0 & 0 & 0 & 0 & 0 & 0 & 0 & 0 & 0 & 0 & 0 & 0 & 0 & $\mathbf{I}$ & . & 0 \\
\hline & 7 & & & & & & & 0 & . & 0 & . & 0 & 0 & 0 & 0 & 0 & 0 & 0 & 0 & 0 & 0 & 0 & 0 & 0 & . & 0 \\
\hline & 8 & & & & & & & & 0 & . & $\mathbf{I}$ & . & 0 & 0 & 0 & 0 & 0 & 0 & 0 & 0 & 0 & 0 & 0 & I & . & $\mathbf{I}$ \\
\hline & 2 & & 8 & & 12 & 7 & 28 & IO & 12 & 5 & 12 & I6 & 24 & 20 & 7 & 23 & 19 & 30 & 13 & 9 & 7 & 8 & 5 & 10 & . & 3 \\
\hline
\end{tabular}

TABLE I 8

Cothill. Females

July 1949

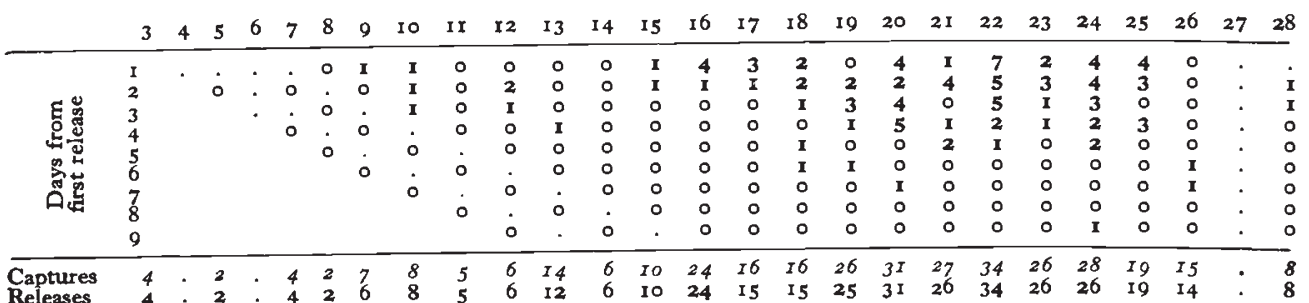


TABLE 19

Sheepstead Hurst. Males

July 1949

\begin{tabular}{|c|c|c|c|c|c|c|c|c|c|c|c|c|c|c|c|c|c|c|c|c|c|c|c|c|c|}
\hline & 3 & 4 & 5 & 6 & 7 & 8 & 9 & Io & II & 12 & 13 & 14 & 15 & 16 & 17 & 18 & 19 & 20 & $2 I$ & 22 & 23 & 24 & 25 & 26 & 2 \\
\hline & I & . & . & . & . & 0 & 0 & o & 0 & $\mathbf{I}$ & 0 & 0 & 2 & 0 & 0 & 0 & 2 & 3 & I & 0 & . & . & 0 & 0 & \\
\hline 듕 & 2 & & $\dot{0}$ & . & $\dot{I}$ & . & 0 & o & 0 & 2 & 0 & 2 & 0 & I & 0 & I & 0 & 2 & 0 & 0 & . & $\dot{0}$ & $\cdot$ & 0 & . \\
\hline 5 & 3 & & & . & . & 0 & . & 0 & 0 & $\bar{I}$ & 0 & I & 0 & 0 & I & I & 0 & 0 & 0 & I & . & 0 & 0 & . & . \\
\hline$\infty$ & 4 & & & & 0 & . & 0 & . & 0 & 0 & 0 & 0 & 0 & 0 & 0 & 0 & I & 0 & 0 & 2 & . & I & 0 & I & . \\
\hline बे & 5 & & & & & 0 & . & 0 & . & 0 & 0 & 0 & 0 & 0 & 0 & 0 & 0 & 0 & 0 & 0 & . & I & 0 & 0 & . \\
\hline 01 & 6 & & & & & & 0 & . & 0 & . & 0 & 0 & I & 0 & 0 & I & 0 & 0 & 0 & 0 & . & 0 & 0 & 0 & . \\
\hline
\end{tabular}

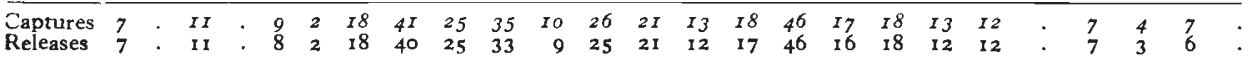

TABLE 20

Sheepstead Hurst. Females

July 1949

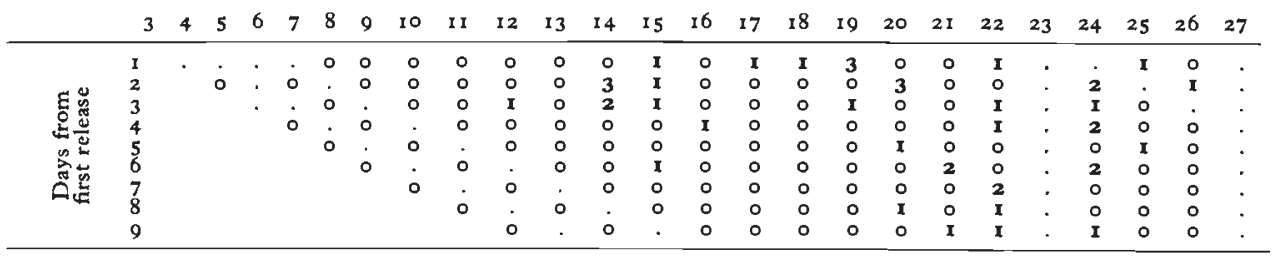

\begin{tabular}{llllllllllllllllllllllllll}
\hline Captures & 7 & $*$ & 5 & 5 & 5 & 3 & 6 & 5 & $I I$ & 26 & 6 & $2 I$ & 22 & $2 I$ & 10 & $2 I$ & 19 & $2 I$ & $2 I$ & 28 &. & 30 & $2 I$ & 9 &. \\
Releases & 7 &. & 5 &. & 3 & 3 & 6 & 4 & 11 & 26 & 6 & 21 & 20 & 18 & 10 & 20 & 16 & 21 & 21 & 28 &. & 30 & $2 I$ & 7 &.
\end{tabular}

TABLE 21

\section{Cothing. Males}

July $195^{\circ}$

Augus

$\begin{array}{lllllllllllllllllllllllllllllll}5 & 6 & 7 & 8 & 9 & 10 & 11 & 12 & 13 & 14 & 15 & 16 & 17 & 18 & 19 & 20 & 21 & 22 & 23 & 24 & 25 & 26 & 27 & 28 & 29 & 30 & 31 & 1 & 2 & 3\end{array}$

\begin{tabular}{|c|c|c|c|c|c|c|c|c|c|c|c|c|c|c|c|c|c|c|c|c|c|c|c|c|c|c|c|c|c|c|}
\hline & I & 0 & 0 & 2 & $\mathbf{I}$ & 0 & 2 & I & 8 & 3 & I & 2 & 2 & 3 & 5 & 2 & 4 & 2 & 3 & 3 & 3 & 6 & 2 & 2 & 3 & I & $\mathbf{I}$ & & 0 & 0 \\
\hline 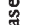 & 2 & & 0 & 0 & 0 & 0 & 0 & 3 & I & 2 & I & 3 & I & 3 & 2 & 3 & 2 & I & I & I & 2 & 2 & 0 & 4 & 2 & I & 2 & 0 & 0 & 0 \\
\hline 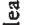 & 3 & & & 0 & 0 & 0 & 0 & 2 & 2 & 2 & 4 & I & 0 & 2 & 0 & 0 & 0 & 4 & $\mathbf{I}$ & 0 & 0 & I & 2 & 2 & 2 & 0 & 2 & 0 & 0 & 0 \\
\hline $\bar{d}$ & 4 & & & & 0 & 0 & I & 2 & 0 & 2 & 2 & 2 & I & I & 0 & 3 & 0 & I & I & 2 & 3 & 2 & 0 & 3 & 2 & I & 0 & 0 & 0 & 0 \\
\hline 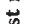 & 5 & & & & & 0 & I & I & 0 & 0 & 2 & I & 2 & 2 & 0 & 3 & 0 & I & I & 3 & 2 & I & 0 & 2 & 2 & I & 2 & 0 & $\mathbf{I}$ & 0 \\
\hline 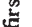 & 6 & & & & & & 0 & I & I & 0 & 0 & 0 & 0 & 3 & 3 & 2 & 0 & 0 & $\mathbf{I}$ & 2 & 2 & I & 0 & $\mathbf{I}$ & 3 & 0 & $\mathbf{I}$ & 0 & 0 & 0 \\
\hline & 7 & & & & & & & 0 & 0 & 0 & 0 & 0 & 0 & 2 & 7 & I & 0 & 0 & 0 & I & 0 & 2 & I & 0 & 2 & I & $\mathbf{I}$ & 0 & 0 & 0 \\
\hline$\leftleftarrows$ & 8 & & & & & & & & 0 & 0 & 0 & 0 & 0 & I & 0 & 4 & 0 & 0 & 0 & 0 & 0 & 0 & 0 & $\mathbf{I}$ & 0 & 0 & 0 & 0 & $\mathbf{I}$ & 0 \\
\hline 년 & 9 & & & & & & & & & 0 & 0 & 0 & 0 & 0 & 3 & 0 & 0 & 0 & 0 & 0 & 0 & 0 & 0 & 0 & 0 & 0 & 0 & 0 & 2 & 0 \\
\hline & 10 & & & & & & & & & & 0 & 0 & 0 & 0 & 0 & 0 & 2 & 0 & 0 & 0 & 0 & 0 & 0 & 0 & 0 & 0 & 0 & 0 & 0 & 0 \\
\hline 2 & II & & & & & & & & & & & 0 & 0 & 0 & 0 & 0 & 0 & I & 0 & 0 & 0 & 0 & 0 & 0 & 0 & 0 & 0 & 0 & 0 & 0 \\
\hline 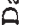 & 12 & & & & & & & & & & & & 0 & 0 & 0 & 0 & 0 & 0 & 0 & I & 0 & 0 & 0 & 0 & 0 & 0 & 0 & 0 & 0 & 0 \\
\hline & 13 & & & & & & & & & & & & & 0 & 0 & 0 & 0 & 0 & 0 & 0 & I & 0 & 0 & 0 & 0 & 0 & 0 & 0 & 0 & 0 \\
\hline
\end{tabular}

$\begin{array}{lllllllllllllllllllllllllllllll}\text { Captures } & 5 & 5 & 14 & 15 & 20 & 33 & 26 & 83 & 32 & 28 & 40 & 39 & 30 & 48 & 51 & 60 & 43 & 37 & 30 & 37 & 40 & 38 & 17 & 21 & 16 & 8 & 15 & 6 & 6 & 1\end{array}$ $\begin{array}{lllllllllllllllllllllllllllllll}\text { Releases } & 5 & 5 & 14 & 15 & 20 & 32 & 26 & 83 & 32 & 28 & 39 & 37 & 30 & 48 & 50 & 57 & 41 & 34 & 30 & 36 & 38 & 37 & 16 & 20 & 16 & 8 & 15 & 6 & 6 & 1\end{array}$

\section{TABLE 22}

\section{Cothill. Females}

July 1950

Auge

$\begin{array}{lllllllllllllllllllllllllllllll}5 & 6 & 7 & 8 & 9 & 10 & 11 & 12 & 13 & 14 & 15 & 16 & 17 & 18 & 19 & 20 & 21 & 22 & 23 & 24 & 25 & 26 & 27 & 28 & 29 & 30 & 31 & 1 & 2 & 3\end{array}$

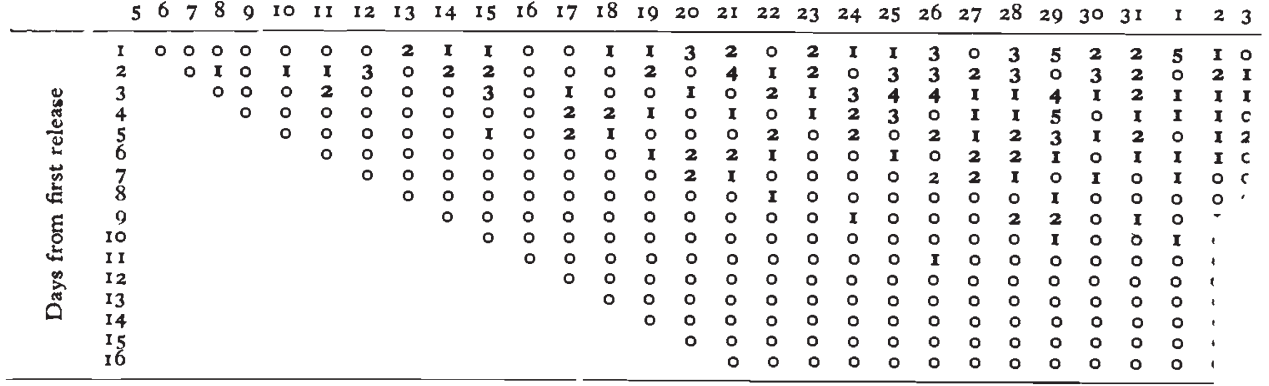

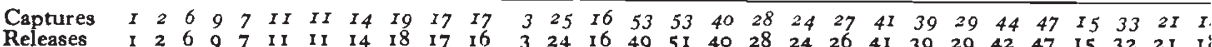


TABLE 23

Sheepstead Hurst. Males

July $195^{\circ}$

August

$\begin{array}{llllllllllllllllllllllllllllll}5 & 6 & 7 & 8 & 9 & 10 & 11 & 12 & 13 & 14 & 15 & 16 & 17 & 18 & 19 & 20 & 21 & 22 & 23 & 24 & 25 & 26 & 27 & 28 & 29 & 30 & 31 & 1 & 2\end{array}$

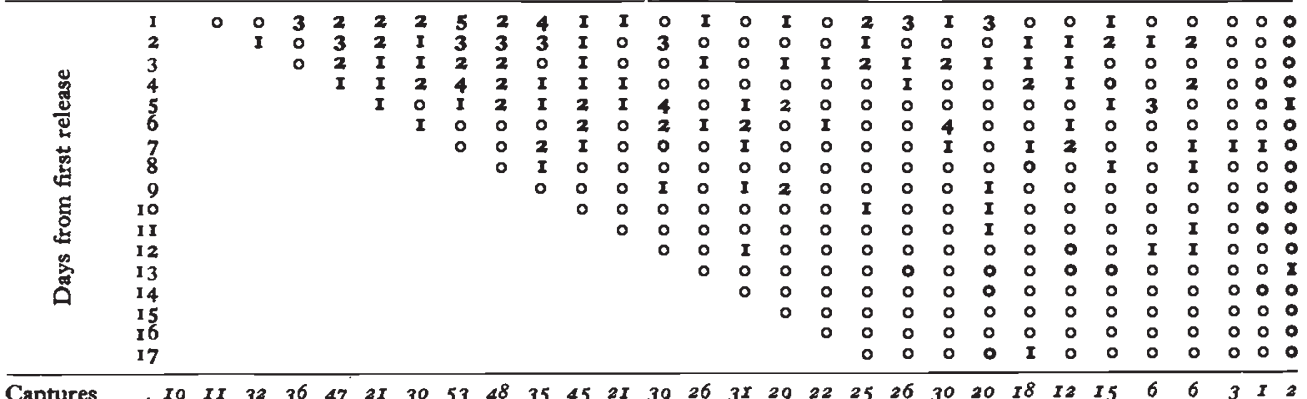

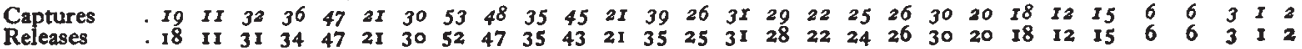

TABLE 24

Shezpstead Hurst. Females

July 1950

August

$\begin{array}{llllllllllllllllllllllllllllll}5 & 6 & 7 & 8 & 9 & 10 & 11 & 12 & 13 & 14 & 15 & 16 & 17 & 18 & 19 & 20 & 21 & 22 & 23 & 24 & 25 & 26 & 27 & 28 & 29 & 30 & 31 & 1 & 2\end{array}$

\begin{tabular}{|c|c|c|c|c|c|c|c|c|c|c|c|c|c|c|c|c|c|c|c|c|c|c|c|c|c|c|c|c|c|c|c|}
\hline 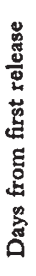 & $\begin{array}{r}1 \\
2 \\
3 \\
4 \\
5 \\
6 \\
7 \\
8 \\
9 \\
10 \\
11 \\
12 \\
13\end{array}$ & 0 & $\begin{array}{l}\mathbf{I} \\
\mathbf{I}\end{array}$ & $\begin{array}{l}0 \\
0 \\
0\end{array}$ & $\begin{array}{l}0 \\
0 \\
0 \\
0\end{array}$ & $\begin{array}{l}0 \\
0 \\
0 \\
0 \\
\text { I }\end{array}$ & $\begin{array}{l}\text { I } \\
0 \\
0 \\
0 \\
0 \\
\mathbf{I}\end{array}$ & o & & $\begin{array}{l}0 \\
\mathbf{I} \\
2 \\
0 \\
0 \\
0 \\
0 \\
0 \\
0\end{array}$ & $\begin{array}{l}0 \\
0 \\
0 \\
0 \\
0 \\
0 \\
0 \\
0 \\
0\end{array}$ & $\begin{array}{l}0 \\
0 \\
0 \\
0 \\
0 \\
0 \\
0 \\
0 \\
0 \\
0\end{array}$ & $\begin{array}{l}I \\
0 \\
0 \\
0 \\
0 \\
I \\
0 \\
0 \\
0 \\
0 \\
0\end{array}$ & $\begin{array}{l}0 \\
0 \\
0 \\
0 \\
0 \\
0 \\
0 \\
0 \\
0 \\
0 \\
0 \\
0\end{array}$ & $\begin{array}{l}I \\
0 \\
0 \\
0 \\
0 \\
0 \\
0 \\
0 \\
I \\
0 \\
0 \\
0 \\
0\end{array}$ & $\begin{array}{l}3 \\
0 \\
0 \\
0 \\
I \\
I \\
0 \\
0 \\
0 \\
0 \\
0 \\
0 \\
0\end{array}$ & $\begin{array}{l}\mathbf{I} \\
0 \\
\mathbf{I} \\
\mathbf{I} \\
\mathbf{I} \\
0 \\
\mathbf{I} \\
0 \\
0 \\
0 \\
0 \\
0 \\
0\end{array}$ & $\begin{array}{l}\mathbf{I} \\
\mathbf{I} \\
0 \\
0 \\
\mathbf{I} \\
0 \\
0 \\
0 \\
0 \\
0 \\
0 \\
\mathbf{I} \\
0\end{array}$ & $\begin{array}{l}\mathbf{I} \\
0 \\
\mathbf{I} \\
0 \\
0 \\
\mathbf{I} \\
0 \\
\mathbf{I} \\
0 \\
\mathbf{I} \\
0 \\
0 \\
0\end{array}$ & $\begin{array}{l}0 \\
0 \\
0 \\
I \\
I \\
0 \\
0 \\
0 \\
0 \\
0 \\
0 \\
0 \\
0\end{array}$ & $\begin{array}{l}0 \\
0 \\
0 \\
2 \\
0 \\
0 \\
1 \\
0 \\
0 \\
0 \\
0 \\
0 \\
0\end{array}$ & $\begin{array}{l}0 \\
\mathbf{I} \\
0 \\
0 \\
0 \\
0 \\
0 \\
0 \\
0 \\
0 \\
0 \\
0 \\
0\end{array}$ & $\begin{array}{l}3 \\
\text { I } \\
0 \\
\text { I } \\
0 \\
\text { I } \\
0 \\
\text { I } \\
0 \\
0 \\
0 \\
0 \\
0\end{array}$ & & $\begin{array}{l}2 \\
0 \\
I \\
0 \\
0 \\
0 \\
2 \\
1 \\
1 \\
0 \\
0 \\
0 \\
0\end{array}$ & $\begin{array}{l}\mathbf{I} \\
\mathbf{I} \\
0 \\
\mathbf{I} \\
\mathbf{I} \\
0 \\
0 \\
2 \\
0 \\
0 \\
0 \\
0 \\
0\end{array}$ & $\begin{array}{l}0 \\
3 \\
1 \\
2 \\
0 \\
1 \\
0 \\
0 \\
0 \\
0 \\
0 \\
0 \\
0\end{array}$ & $\begin{array}{l}0 \\
0 \\
0 \\
0 \\
0 \\
0 \\
0 \\
0 \\
0 \\
0 \\
0 \\
0 \\
0\end{array}$ & $\begin{array}{l}0 \\
0 \\
0 \\
2 \\
0 \\
1 \\
0 \\
2 \\
0 \\
0 \\
1 \\
0 \\
0\end{array}$ & $\begin{array}{l}0 \\
0 \\
I \\
0 \\
I \\
I \\
0 \\
0 \\
0 \\
0 \\
0 \\
0 \\
I\end{array}$ & $\begin{array}{ll}0 & \text { I } \\
0 & 0 \\
\text { I } & 0 \\
0 & 0 \\
\text { I } & 0 \\
\text { I } & 0 \\
0 & 0 \\
0 & 0 \\
0 & 0 \\
0 & 0 \\
0 & 0 \\
0 & 0 \\
1 & 0\end{array}$ \\
\hline
\end{tabular}

$\begin{array}{llllllllllllllllllllllllllllll}\text { Captures . } & 3 & 5 & 7 & 7 & 9 & 9 & 11 & 7 & 16 & 12 & 12 & 21 & 8 & 29 & 28 & 29 & 15 & 21 & 22 & 27 & 19 & 24 & 22 & 16 & 18 & 5 & 20 & 10 & 3\end{array}$

TABLE 25

Sherpstead HURST. Males and females without an extra mark

July 1950

August

$\begin{array}{llllllllllllllllllllllllllllll}5 & 6 & 7 & 8 & 9 & 10 & 11 & 12 & 13 & 14 & 15 & 16 & 17 & 18 & 19 & 20 & 21 & 22 & 23 & 24 & 25 & 26 & 27 & 28 & 29 & 30 & 31 & 1 & 2\end{array}$

\begin{tabular}{|c|c|c|c|c|c|c|c|c|c|c|c|c|c|c|c|c|c|c|c|c|c|c|c|c|c|c|c|c|c|c|c|c|}
\hline 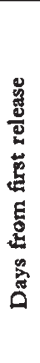 & $\begin{array}{r}1 \\
2 \\
3 \\
4 \\
5 \\
6 \\
7 \\
8 \\
9 \\
10 \\
11 \\
12 \\
13 \\
14 \\
15 \\
16 \\
17\end{array}$ & 0 & $\begin{array}{l}\mathbf{I} \\
0\end{array}$ & $\begin{array}{l}2 \\
0 \\
0\end{array}$ & $\begin{array}{l}2 \\
\mathbf{1} \\
0 \\
\mathbf{I}\end{array}$ & $\begin{array}{l}0 \\
0 \\
0 \\
0 \\
\mathbf{I}\end{array}$ & $\begin{array}{l}\mathbf{I} \\
\mathbf{I} \\
0 \\
0 \\
0 \\
\mathbf{I}\end{array}$ & & $\begin{array}{l}\mathbf{I} \\
\mathbf{I} \\
0 \\
\mathbf{I} \\
0 \\
0 \\
0\end{array}$ & $\begin{array}{l}I \\
2 \\
0 \\
I \\
I \\
0 \\
0 \\
0\end{array}$ & $\begin{array}{l}\mathbf{I} \\
\mathbf{I} \\
0 \\
0 \\
0 \\
0 \\
\mathbf{I} \\
\mathbf{I} \\
0\end{array}$ & $\begin{array}{l}\text { I } \\
0 \\
\text { I } \\
\text { I } \\
2 \\
\text { I } \\
0 \\
0 \\
0 \\
0\end{array}$ & $\begin{array}{l}0 \\
0 \\
0 \\
0 \\
0 \\
1 \\
0 \\
0 \\
0 \\
0 \\
0\end{array}$ & $\begin{array}{l}0 \\
0 \\
0 \\
0 \\
1 \\
0 \\
0 \\
0 \\
1 \\
0 \\
0 \\
0\end{array}$ & $\begin{array}{l}\mathbf{I} \\
0 \\
\mathbf{I} \\
0 \\
0 \\
\mathbf{I} \\
0 \\
0 \\
\mathbf{I} \\
0 \\
0 \\
0 \\
0\end{array}$ & $\begin{array}{l}2 \\
0 \\
0 \\
0 \\
1 \\
2 \\
0 \\
0 \\
0 \\
0 \\
0 \\
0 \\
0 \\
0\end{array}$ & $\begin{array}{l}0 \\
0 \\
0 \\
0 \\
1 \\
0 \\
0 \\
0 \\
0 \\
0 \\
0 \\
0 \\
0 \\
0 \\
0\end{array}$ & $\begin{array}{l}0 \\
0 \\
1 \\
0 \\
0 \\
0 \\
0 \\
0 \\
0 \\
0 \\
0 \\
1 \\
0 \\
0 \\
0 \\
0\end{array}$ & & $\begin{array}{l}2 \\
1 \\
0 \\
0 \\
0 \\
1 \\
0 \\
1 \\
0 \\
0 \\
0 \\
0 \\
0 \\
0 \\
0 \\
0 \\
0\end{array}$ & $\begin{array}{l}2 \\
0 \\
I \\
1 \\
0 \\
0 \\
0 \\
0 \\
0 \\
0 \\
0 \\
0 \\
0 \\
0 \\
0 \\
0 \\
0\end{array}$ & $\begin{array}{l}\text { I } \\
0 \\
I \\
2 \\
0 \\
2 \\
I \\
0 \\
0 \\
0 \\
0 \\
0 \\
0 \\
0 \\
0 \\
0 \\
0\end{array}$ & & $\begin{array}{l}2 \\
0 \\
0 \\
0 \\
0 \\
0 \\
0 \\
0 \\
0 \\
1 \\
0 \\
0 \\
0 \\
0 \\
0 \\
0 \\
0\end{array}$ & $\begin{array}{l}2 \\
2 \\
0 \\
2 \\
0 \\
1 \\
0 \\
0 \\
0 \\
0 \\
0 \\
0 \\
0 \\
0 \\
0 \\
0 \\
1\end{array}$ & $\begin{array}{l}0 \\
\mathbf{I} \\
2 \\
0 \\
0 \\
\mathbf{1} \\
\mathbf{3} \\
0 \\
0 \\
0 \\
0 \\
0 \\
0 \\
0 \\
0 \\
0 \\
0\end{array}$ & $\begin{array}{l}0 \\
1 \\
0 \\
0 \\
0 \\
0 \\
0 \\
2 \\
0 \\
0 \\
0 \\
0 \\
0 \\
0 \\
0 \\
0 \\
0\end{array}$ & $\begin{array}{l}0 \\
I \\
0 \\
0 \\
2 \\
0 \\
0 \\
0 \\
0 \\
0 \\
0 \\
1 \\
0 \\
0 \\
0 \\
0 \\
0\end{array}$ & & $\begin{array}{l}0 \\
I \\
0 \\
0 \\
0 \\
0 \\
0 \\
0 \\
0 \\
0 \\
0 \\
0 \\
0 \\
0 \\
0 \\
0 \\
0 \\
0\end{array}$ & $\begin{array}{l}0 \\
0 \\
0 \\
\mathbf{I} \\
0 \\
0 \\
0 \\
\mathbf{I} \\
0 \\
0 \\
0 \\
0 \\
0 \\
0 \\
0 \\
0 \\
0\end{array}$ & $\begin{array}{l}0 \\
0 \\
0 \\
0 \\
0 \\
0 \\
I \\
0 \\
0 \\
0 \\
0 \\
0 \\
0 \\
0 \\
0 \\
0 \\
0\end{array}$ \\
\hline
\end{tabular}

\begin{tabular}{llllllllllllllllllllllllllllllllll}
\hline Releases. & 10 & 8 & 18 & 20 & 28 & 13 & 20 & 27 & 30 & 23 & 28 & 19 & 19 & 28 & 29 & 25 & 18 & 22 & 23 & 31 & 18 & 23 & 17 & 14 & 10 & 4 & 10 & 6 & 3
\end{tabular} 
top of the column and the time, in days, from its first release on the left-hand side of the table.

The daily population size of a colony can be estimated from the number of marks available for recapture on any day as well as the number of insects caught and marks retaken. However, at the be-

TABLE 26

Sheepstead Hurst. Males and females with an extra mark

July 1950

$\begin{array}{lllllllllllllllllllllllllll}5 & 6 & 7 & 8 & 9 & 10 & 11 & 12 & 13 & 14 & 15 & 16 & 17 & 18 & 19 & 20 & 21 & 22 & 23 & 24 & 25 & 26 & 27 & 28 & 29 & 30 & 31\end{array}$

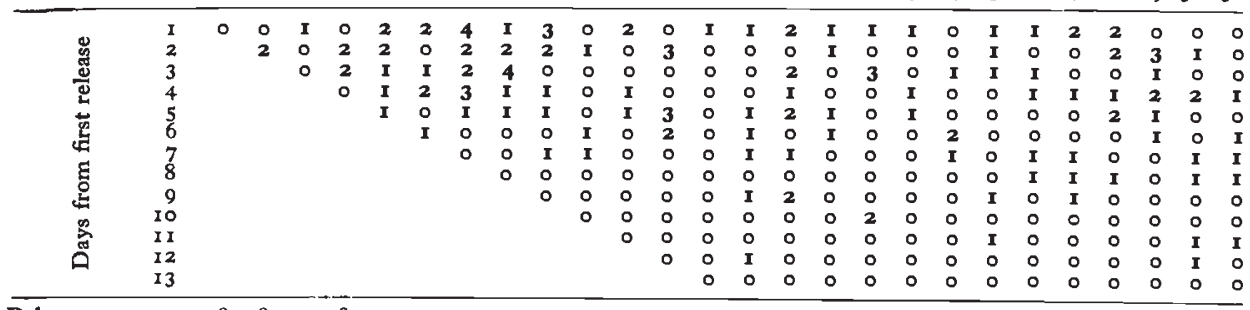

ginning of the season when the number of marks in the population is small and at the end of the season when the samples are often small, there are days on which no marked insects are caught. Furthermore, there are some days in the middle of the season when collecting is impossible. It is therefore essential to have a method of estimating an average population size over a number of days so that an idea of the size of the daily population can be obtained for all days in the season. This average population size for a number of days is best obtained by multiplying the estimated number of marks by the size of the sample for separate days, summing them, and dividing this by the sum of marks recaptured over the days in question. This method gives greater weight to the larger samples and to the days when the greatest number of marks were available for recapture. The number of insects in the colony in the last few days of the season can be estimated by taking the average population size for the last three days on which reasonable samples can be obtained and then reducing this from day to day using the known rate of daily elimination. If this is done and if collecting started at the beginning of the season, when very few moths were available for capture, the seasonal population size can be obtained by dividing the sum of the daily population sizes for the whole season by the expectation of life (one hundred divided by the percentage daily elimination of moths). Tables 27 to $3^{2}$ give the daily population size for the different seasons averaged over short periods (usually three days) as well as the observed sex ratio for 1949 and 1950 . Table 33 gives seasonal population sizes for 1947 to $195^{\circ}$. The fact that the sex ratio changes from day to day as judged by daily samples of insects from the colony and estimated population sizes, is of extreme importance because it gives a measure 
of the accuracy of the estimates of daily population sizes. This change is also an important part of the breeding structure of the colony. Figs. 4 and 5 show the average daily population size for three day

TABLE 27

TABLE 28

Cothill 1947

Cotrill 1948

\begin{tabular}{|c|c|c|c|}
\hline Date & Population size & Date & Population size \\
\hline $\begin{array}{l}\text { July } 14-17 \\
\text { July } 18-20 \\
\text { July } 21-23 \\
\text { July } 24-27\end{array}$ & $\begin{array}{l}1963 \\
1572 \\
1437 \\
1282\end{array}$ & $\begin{array}{l}\text { July } 6-10 \\
\text { July } 11-13 \\
\text { July } 14-16 \\
\text { July } 17-19 \\
\text { July } 20-22 \\
\text { July } 23-25 \\
\text { July } 26-28 \\
\text { July } 29-31\end{array}$ & $\begin{array}{l}145 \\
180 \\
424 \\
459 \\
479 \\
535 \\
600 \\
645\end{array}$ \\
\hline
\end{tabular}

TABLE 29

CothILl 1949

\begin{tabular}{|c|c|c|c|c|c|c|}
\hline \multirow{2}{*}{ Date } & \multicolumn{3}{|c|}{ Insects captured } & \multicolumn{3}{|c|}{ Estimated daily population size } \\
\hline & Females & Males & $\begin{array}{l}\text { Per cent. } \\
\text { males }\end{array}$ & Females & Males & $\begin{array}{l}\text { Per cent. } \\
\text { males }\end{array}$ \\
\hline July 5-10 & 23 & 67 & $74 \cdot 4$ & 25 & 120 & $82 \cdot 8$ \\
\hline July I I - I 3 & 25 & 31 & $55 \cdot 4$ & 64 & 73 & $53 \cdot 3$ \\
\hline July I 4 - 16 & $4^{\mathrm{O}}$ & $6_{4}$ & $61 \cdot 5$ & 89 & I I 3 & $55 \cdot 9$ \\
\hline July I $7-19$ & 58 & $5 \mathrm{I}$ & $46 \cdot 8$ & $9 \mathrm{I}$ & I 28 & $58 \cdot 4$ \\
\hline July 20-22 & 92 & 55 & $37 \cdot 4$ & 90 & I I 7 & $56 \cdot 5$ \\
\hline July $23^{-25}$ & 73 & 20 & $21 \cdot 5$ & 120 & $5^{\circ}$ & $29 \cdot 4$ \\
\hline July $26-28$ & 23 & I 4 & $37 \cdot 8$ & 239 & 29 & $10 \cdot 8$ \\
\hline
\end{tabular}

TABLE 30

SheEpstead HuRst 1949

\begin{tabular}{|c|c|c|c|c|c|c|}
\hline \multirow{2}{*}{ Date } & \multicolumn{3}{|c|}{ Insects captured } & \multicolumn{3}{|c|}{ Estimated daily population size } \\
\hline & Females & Males & $\begin{array}{l}\text { Per cent. } \\
\text { males }\end{array}$ & Females & Males & $\begin{array}{c}\text { Per cent. } \\
\text { males }\end{array}$ \\
\hline $\begin{array}{ll}\text { July } & 5-15 \\
\text { July } 16-18 \\
\text { July } 19-2 \text { I } \\
\text { July } 22-24 \\
\text { July } 25^{-28}\end{array}$ & $\begin{array}{r}110 \\
52 \\
61 \\
58 \\
33\end{array}$ & $\begin{array}{r}198 \\
77 \\
48 \\
19 \\
13\end{array}$ & $\begin{array}{l}64 \cdot 3 \\
59 \cdot 7 \\
44 \cdot 0 \\
24 \cdot 7 \\
28 \cdot 3\end{array}$ & $\begin{array}{l}271 \\
9 \text { I } 8 \\
3 \text { I } 2 \\
255 \\
808\end{array}$ & $\begin{array}{r}424 \\
420 \\
224 \\
83 \\
126\end{array}$ & $\begin{array}{l}6 I \cdot 0 \\
3 I \cdot 4 \\
4 I \cdot 8 \\
24 \cdot 6 \\
I 3 \cdot 5\end{array}$ \\
\hline
\end{tabular}

periods at Cothill and Sheepstead Hurst in 1950, where the estimated and observed sex ratios agree moderately well. Although the estimates of daily population size show considerable fluctuations because of 
sampling errors, it can be seen that the maximum population size of males is reached before that for females. This ensures that the largest

TABLE 31

Cothill 1950

\begin{tabular}{|c|c|c|c|c|c|c|}
\hline \multirow{2}{*}{ Date } & \multicolumn{3}{|c|}{ Insects captured } & \multicolumn{3}{|c|}{ Estimated daily population size } \\
\hline & Females & Males & $\begin{array}{l}\text { Per cent. } \\
\text { males }\end{array}$ & Females & Males & $\begin{array}{l}\text { Per cent. } \\
\text { males }\end{array}$ \\
\hline July $6-8$ & 17 & 34 & $66 \cdot 7$ & 72 & 173 & $70 \cdot 6$ \\
\hline July $9-11$ & 29 & 79 & $73 \cdot I$ & 116 & 563 & $82 \cdot 9$ \\
\hline July 12-14 & $5^{\circ}$ & 143 & $74 \cdot 1$ & 191 & 355 & 65.0 \\
\hline July $15-17$ & 45 & 109 & $70 \cdot 8$ & 148 & 454 & $75 \cdot 4$ \\
\hline July $18-20$ & 122 & 154 & $56 \cdot 6$ & 437 & 334 & $43 \cdot 3$ \\
\hline July $21-23$ & 92 & 110 & 54.5 & 414 & 569 & 57.9 \\
\hline July $24-26$ & 107 & 115 & $5 I \cdot 8$ & 305 & 333 & $52 \cdot 2$ \\
\hline July $27-29$ & 120 & 54 & $3^{1} \cdot 0$ & 301 & I55 & $34^{\circ} \mathrm{O}$ \\
\hline July $30-$ I & 69 & 29 & $29 \cdot 6$ & 275 & 146 & 34.7 \\
\hline Aug. 2- 4 & 45 & 12 & $2 I \cdot I$ & 179 & 105 & $37^{\circ} 0$ \\
\hline
\end{tabular}

TABLE 32

SheEPSTEAd HURST 1950

\begin{tabular}{|c|c|c|c|c|c|c|}
\hline \multirow{2}{*}{ Date } & \multicolumn{3}{|c|}{ Insects captured } & \multicolumn{3}{|c|}{ Estimated daily population size } \\
\hline & Females & Males & $\begin{array}{l}\text { Per cent. } \\
\text { males }\end{array}$ & Females & Males & $\begin{array}{l}\text { Per cent. } \\
\text { males }\end{array}$ \\
\hline July 6-9 & 28 & 126 & $8 I \cdot 8$ & 109 & 422 & \\
\hline July 10-12 & 27 & 104 & 79.4 & 197 & 315 & $\begin{array}{l}y .3 \\
6 I \cdot 5\end{array}$ \\
\hline July $13^{-15}$ & 40 & 128 & $76 \cdot 2$ & 462 & 493 & $5 I \cdot 6$ \\
\hline July $16-18$ & 58 & 86 & $59 \cdot 7$ & 699 & 696 & 49.9 \\
\hline July I9-2 I & 72 & 82 & $53 \cdot 2$ & 377 & 710 & 65.3 \\
\hline July 22-24 & 70 & 81 & $53 \cdot 6$ & 609 & 466 & $43 \cdot 3$ \\
\hline July $25-27$ & 65 & 50 & 43.5 & $4^{16}$ & 273 & $\begin{array}{l}45.3 \\
39 \cdot 6\end{array}$ \\
\hline July 28-30 & 39 & 27 & 40.9 & 290 & 122 & $29 \cdot 6$ \\
\hline July $31-2$ & 33 & & 15.4 & 246 & 77 & $23 \cdot 8$ \\
\hline
\end{tabular}

TABLE 33

Approximate estimates of seasonal population sizes

\begin{tabular}{|c|c|c|c|c|}
\hline Year & Locality & Males & Females & Totals \\
\cline { 5 - 5 } 1947 & Cothill & $\ldots$ & $\ldots$ & \\
1948 & $\#$ & $\ldots$ & $\ldots$ & $5000-7000$ \\
1949 & $\#$ & 938 & 797 & $2600-3800$ \\
1950 & Sheepstead Hurst & 2381 & 1741 & $1400-2000$ \\
1949 & 2563 & 2976 & $3500-4700$ \\
1950 & $\#$ & 2323 & 1934 & $5000-6000$ \\
& & & & \\
\hline
\end{tabular}

number of females are mated in the shortest time. For it will be remembered that the females only mate once but that the males are 
capable of copulating successfully with a large number of females. Consequently, the important ratio from the point of view of breeding structure is not the ratio of males to females in the colony on any one day, but the ratio of males to newly emerged females. This mating

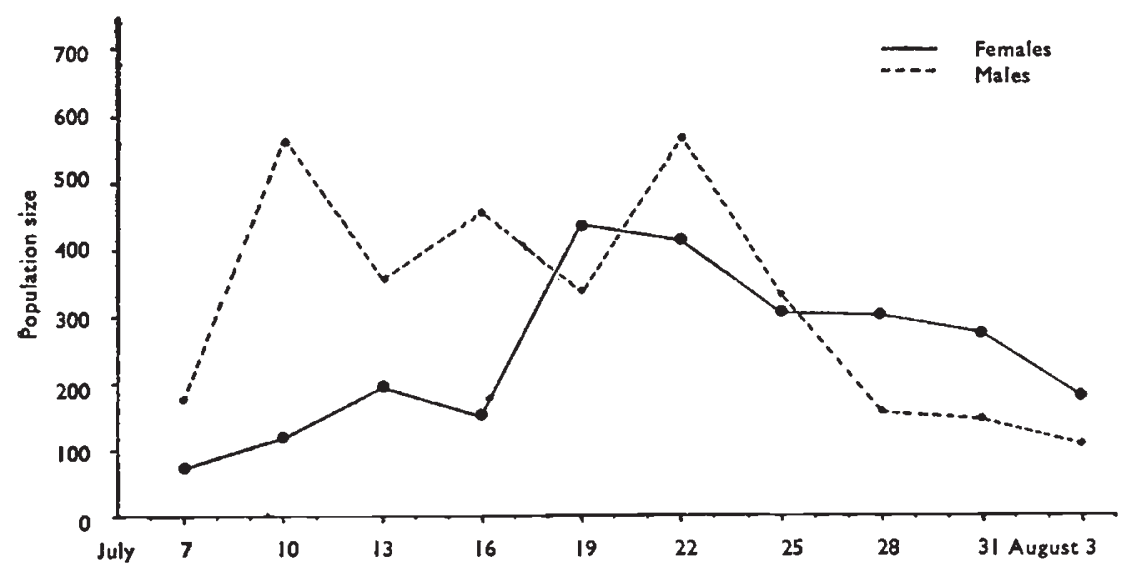

FIG. 4.-The daily population sizes at Cothill in 1950 have been averaged over short periods to minimise fuctuations resulting from sampling errors.

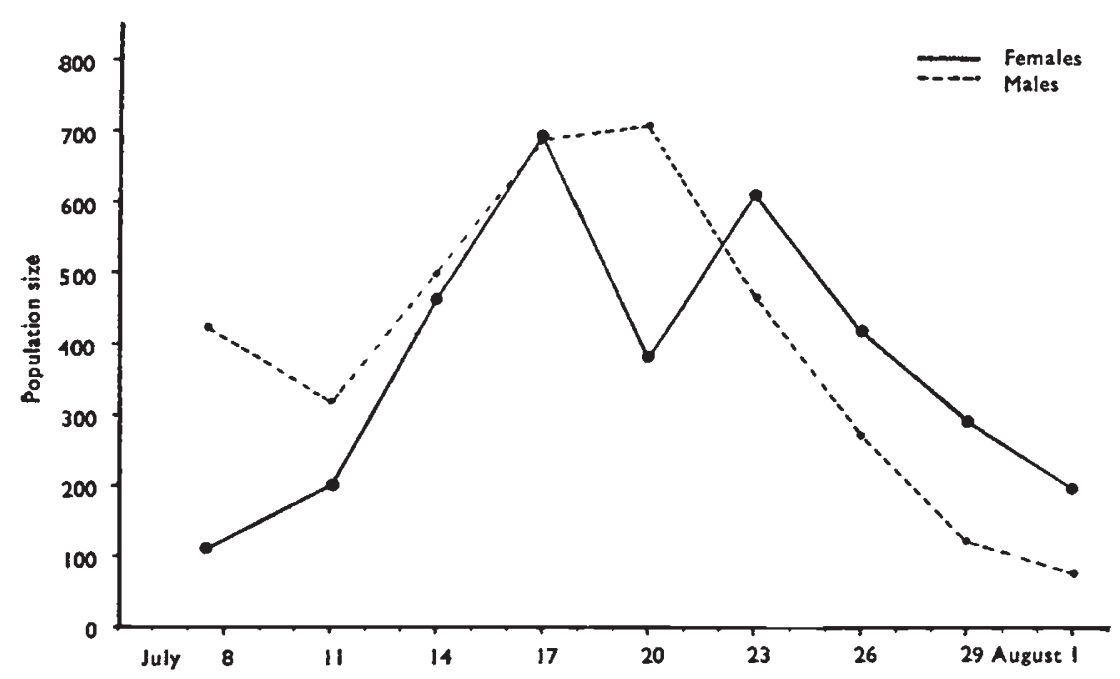

Frg. 5. - The diagram shows changes in population size in the Sheepstead Hurst colony during the 1950 season. There is a clear indication that males tend to emerge before the females.

system will reduce the effective population size by a small amount. However, this reduction will not be great, although its size cannot be estimated until it is known how much the ability of a male to copulate is impaired by previous matings. Selection in this type of breeding-community will be heavily in favour of any character which enables a male to find and mate with a female quickly. 
It is unlikely that the early emergence of males is a function of the size of the pupa but is probably due to a complex physiological process which is subject to alterations through the agency of natural selection. The view that the timing of emergence of the two sexes is of a complex nature receives some support from the fact that in a brood of larvæ, which fed up rapidly in I950, and emerged in October, instead of hibernating in the third instar, the males emerged later than the females instead of earlier as is normal. Selection for the accurate timing of the date of emergence must be heavy in $P$. dominula where the longest expectation of life, recorded since I940, was $8 \cdot 70$ days and the shortest only $2 \cdot 24$ days. Dowdeswell, Fisher and Ford (1949) give the change in sex ratio and daily population size in Maniola jurtina L. on the Isles of Scilly, and again the same change in sex ratio from day to day is observed, although they seem to have started collecting about the middle of the season when the male population was at its maximum. It would be interesting to know if Gonepteryx rhamni L., and other single brooded butterflies which hibernate in the adult state and do not copulate till the spring, show the same early emergence of the males, and whether they come out of hibernation first. Moreover, it would be most interesting to make a comparison between species which hibernate as eggs, larvæ, or pupæ; as adults, but with only one brood, as adults with more than one brood, and as adults with one brood in some areas and two in others.

\section{DISCUSSION}

The previous investigation into population size and the spread of the medionigra gene in an isolated colony of $P$. dominula by Fisher and Ford (1947) showed that the fluctuations in the gene frequency were too great to be ascribed to "genetic drift." On the other hand Wright (1948) has pointed out that the authors give no indication of the size of fluctuations in the selective value of the variant gene necessary to account for the observed changes in gene frequency. From the observed fluctuations he estimated that the selective value of the heterozygote medionigra would vary between semi-lethality and an advantage of $5^{\circ}$ per cent. over dominula in the course of half a century. However, in arriving at this conclusion he assumes that the selective value " has no trend but varies according to non-secular fluctuations in conditions from year to year." On the contrary, the data for the years 1939 to 1950 give no indication that the relative selective advantages of the three genotypes has varied over this period. The disadvantage of the heterozygote over typical dominula was about Io per cent. Between I929 and I939 the medionigra gene undoubtedly spread at a speed consistent with a selective advantage of about 20 per cent. An alternative hypothesis is that between I 929 and I 939 the population was reduced to an exceedingly small size on two or more occasions and that the gene increased in frequency 
by "drift." However, Dr E. B. Ford informs me that he has written to many of the entomologists who collected $P$. dominula, at Cothill, between 1929 and 1939. At least one person collected each year and none record difficulty in obtaining a good "series" of moths on suitable days. The scarcity of moths would undoubtedly have been noticed if the seasonal population size had ever been reduced to a few hundred individuals. On the other hand, the populations of Euphydryas aurinia (Rott.) at Cothill and $P$. dominula at Tubney Wood have fluctuated in the past; a fact that has been recorded. The Tubney Wood colony was thought to be extinct, but actually the moths are still present at a very low density.

One other important suggestion made by Wright is that the effective and apparent population sizes may be very different. He suggests that if a female lays the majority of her eggs in one place, the offspring will be subjected to a similar environment and whole broods may either tend to all survive or all to be killed. Although it is agreed that experiments to determine the relationship between effective and apparent population size in many different types of breeding-community are essential, it must be pointed out that a large number of solitary insects, in fact, scatter their eggs over a wide area. The evidence obtained on the egg-laying habits of $P$. dominula both in the field and in the laboratory, as well as observations on the behaviour of the larvæ do not support the hypothesis that the fate of any individual is correlated with the fate of the brood through the agency of fortuitous fluctuations in the environment.

Because of the importance of this point, it is worth while reconsidering the evidence for it. Although Kettlewell (1942) considers that females lay a large proportion of their eggs in the area in which they themselves emerged from the pupa, the evidence of laboratory animals indicates that only a small proportion of the eggs are deposited in the first twenty-four hours after copulation. Moreover, field observations confirm this to some extent for females recaptured five, six, seven and eight days after they were first marked have frequently laid over a dozen fertile eggs during the hour or two between recapıure and subsequent release. There is evidence from both Sheepstead Hurst and Cothill that females do, in fact, fly shortly after copulation. Lastly the eggs are not laid in batches, which adhere to a leaf or other object as in the majority of lepidoptera, but have no adhesive substance and are scattered freely over the vegetation. The type of habitat usually occupied by $P$. dominula is rough and much sub-divided by tussocks, reeds, bushes and trees so that even quite a small expansion of the area occupied by a brood, through the movement of the individuals in it, would ensure that it occupied a large number of microhabitats. The larvæ can move considerable distances and have been found as much as twenty feet up trees and they are also known to move from plant to plant. Because much of the elimination takes place in the late larval and pupal life, and because the larvæ scatter 
from the food plant to pupate and are therefore less likely all to be influenced by the same micro-environment, it was decided to investigate the elimination of larvæ in the last instar. Twenty-two isolated Comfrey plants were selected at random from a much larger number of suitable plants and five larvæ which had just moulted into the last larval instar were placed on each. Isolated plants or plants in isolated clumps were used so that the possibility of larvæ emigrating or immigrating was minimised. A similar batch of larvæ was kept in the laboratory in order that the time of onset of pupation would be known, making certain that the results were not due to loss of larvæ by dispersal prior to pupation. The results of counts of larvæ on twenty-two plants on several occasions is given in table 34 . The

TABLE 34

\begin{tabular}{|c|c|c|c|c|c|c|c|c|c|}
\hline \multirow{2}{*}{$\begin{array}{c}\text { Number } \\
\text { of } \\
\text { plant }\end{array}$} & \multicolumn{4}{|c|}{ Number of larvæ still alive } & \multirow{2}{*}{$\begin{array}{c}\text { Number } \\
\text { of } \\
\text { plant }\end{array}$} & \multicolumn{4}{|c|}{ Number of larvæ still alive } \\
\hline & April 30 & May 3 & May 10 & May 14 & & April 30 & May 3 & May 10 & May 14 \\
\hline$I$ & 5 & 1 & 1 & 0 & 12 & 5 & 5 & 0 & 0 \\
\hline 2 & 5 & 2 & 0 & 0 & 13 & 5 & 2 & 0 & 0 \\
\hline 3 & 5 & 2 & 1 & 0 & 14 & 5 & 0 & 0 & 0 \\
\hline 4 & 5 & 3 & 0 & 0 & 15 & 5 & 2 & 1 & I \\
\hline 5 & 5 & 1 & 0 & 0 & 16 & 5 & 2 & 0 & 0 \\
\hline 6 & 5 & 4 & 3 & 1 & 17 & 5 & 2 & 0 & 0 \\
\hline 7 & 5 & $i$ & o & 0 & 18 & 5 & 2 & o & 0 \\
\hline 8 & 5 & 3 & I & 0 & 19 & 5 & 4 & 0 & 0 \\
\hline 9 & 5 & o & 0 & 0 & 20 & 5 & 3 & I & 0 \\
\hline Io & 5 & 3 & 0 & 0 & $2 I$ & 5 & I & 0 & 0 \\
\hline \multirow[t]{2}{*}{ II } & 5 & 2 & 2 & 0 & 22 & 5 & 5 & 1 & o \\
\hline & & & & & & 110 & 50 & 11 & 2 \\
\hline
\end{tabular}

data give no indication that there is a non-random elimination of larvæ with respect to plants. The experiment was not continued after i $4^{\text {th }}$ May because only two larvæ remained and on that date some larvæ in the laboratory started to pupate.

It is hoped to continue these experiments as well as to undertake others on the size of the larval population in the spring and the extent to which larvæ move from place to place, using genetically marked individuals. The two populations at Sheepstead Hurst and Cothill afford a unique opportunity not only for studying the changes in the selective value of certain genes, but also the breeding structure of populations and the factors controlling population size. At the moment it is possible to say that the general environment and the genetical composition of the two colonies is different although they are situated near one another. Also the changes in population size, which must be affected to a small extent by the number of eggs laid, and therefore the death-rate of adults, are not the same in the two localities. 
It will be of interest in a few years time when the difference in the ecology of the two colonies is better known, to introduce the medionigra gene into the new colony and compare its behaviour in the two populations. Many inherited characters found in wild populations have been claimed as being of neutral survival value and the differences in their frequency in different populations has been attributed to "genetic drift" (e.g. Diver, I940 ; Mayr, I 942). However, some of these factors as well as others which have been quoted as demonstrating "genetic drift" have since been shown to have considerable selective values (Dobzhansky, I943, I948; Carson and Stalker, I949; Cain and Sheppard, I950; and Sheppard, 195I). The apparent 20 per cent. selective advantage of the medionigra gene between 1929 and 1939 and its 1o per cent. disadvantage between r 939 and r950, without any detectable sustained change in the environment, demonstrate very clearly how dangerous and misleading it is to claim that certain characters are neutral in survival value, even after quite extensive investigations.

\section{SUMMARY}

I. Two natural populations of the single-brooded moth Panaxia dominula L. (Arctiidæ), at Cothill and Sheepstead Hurst, Berkshire, have been investigated. Though situated only a mile apart, it was shown that their genetic compositions, as well as their environments, were different.

2. The Cothill colony had been under detailed observation since 1939. By means of marking the moths with cellulose paint, Fisher and Ford (1947) had determined the frequency of the medionigra gene from 1939 to 1946 , and the population size from I94 to 1946 . The present paper extends these data to I950.

3. It further shows that specimens heterozygous for the medionigra gene have been at a disadvantage of approximately ro per cent. each year since 1939, though it is clear that they must have had a considerable selective advantage from 1929 to $193^{8 .}$

4. Similar records for population-size are now provided for the second colony (at Sheepstead Hurst) for I 949 and I950. Medionigra does not occur here.

5. A new variety of the moth was discovered in 1948 . The form is genetically determined, but the exact nature of its control is still under investigation. Its frequency differs significantly in the two colonies.

6. A study of daily population sizes, and of the changes in sex-ratio, demonstrate that the males emerge earlier than the females.

7. There is no evidence that the marking of $P$. dominula alters its expectation of life, but there is some suggestion that it may affect the ease with which specimens can be caught (but see Note, p. 378.)

8. Fisher and Ford (1947) showed that the observed fluctuations in the frequency of the medionigra gene at Cothill must be controlled 
by selection, and could not be attributed to "genetic drift" in the manner suggested by Sewall Wright. This has been further confirmed, and the criticisms made by Wright of the earlier part of this work are shown to be invalid (see Discussion).

Acknowledgments.-I am much indebted to Professor R. A. Fisher and Dr E. B. Ford for their kindness in encouraging me to make observations and collect data at Cothill for the continuance of the experiment which they started in 1939, and also for reading this paper in manuscript. Mr D. J. Finney, Mr J. M. Hammersley and $\mathrm{Mr}$ M. R. Sampford have assisted me with statistical advice and with some of the calculations. During part of the investigation I received a grant from the Department of Scientific and Industrial Research, for which grateful acknowledgment is made.

Note.-The data for 1951 make it unlikely that marking affects the case of recapture.

\section{REFERENCES}

CAIN, A. J., AND SHEPpard, P. M. 1950. Selection in the polymorphic land snail Cepea nemoralis. Heredity, 4, 275-294.

CARSON, H. W., AND STALKER, H. D. 1949. Seasonal variation in gene arrangement frequencies over a three-year period in Drosophila robusta, Sturtevant. Evolution, 3, 322-329.

DIVER, c. 1940. The problem of closely related species living in the same area. In The New Systematics. Ed. Huxley. London: Oxford University Press.

Dobzhansky, T. 1943. Genetics of natural populations. IX. Temporal changes in the composition of populations of Drosophila pseudoobscura. Genetics, 28, 162-1 86.

DoBzhansky, T. 1948. Genetics of natural populations. XVI. Altitudinal and seasonal changes produced by natural selection in certain populations of Drosophila pseudoobscura and Drosophila persimilis. Genetics, 33, I58-1 76.

DOWDESWELL, W. H., FISHER, R. A., AND FORD, E. B. 1940. The quantitative study of populations in the Lepidoptera. Ann. Eugen., ro, I23-1 36.

DOWDESWELL, W. H., FISHER, R. A., AND FORD, E. B. 1949. The quantitative study of populations in the Lepidoptera. 2. Maniola jurtina L. Heredity, 3, 67-87.

FISHER, R. A., AND FORD, E. B. 1947. The spread of a gene in natural conditions in a colony of the moth Panaxia dominula L. Heredity, $x, 143^{-1} 74$.

HARDY, G. H. 1908. Mendelian proportions in a mixed population. Science, 28, 49-50.

KeTtrewell, H. B. D. 1942. A survey of the insect Panaxia (Callimorpha) dominula L. Proc. S. Lond. ent. Nat. Hist. Soc. (1942-43), pp. I-49.

MAYR, E. 1942. Systematics and the Origin of Species. New York (Columbia).

SHEPPARD, P. M. I95I. Fluctuations in the selective value of certain phenotypes in the polymorphic land snail, Cepea nemoralis L. Heredity, 5, 125-1 34 .

WRIGHT, s. 1948. On the roles of directed and random changes in gene frequency in the genetics of populations. Evolution, 2, no. 4, 279-294. 